\title{
남미 볼리비아 수자원 관리 및 관개농업 시스템 개선을 위한 국제개발협력
}

하 상 섭 한국외대 한중남미녹색융합센터 연구교수

\begin{tabular}{|l|} 
목차 \\
I. 들어가며 \\
II. 볼리비아 수자원 현황 및 수자원 관리 \\
III. 볼리비아 농업발전과 관개농업의 영향 \\
IV. 나오며
\end{tabular}

주제어: 볼리비아, 수자원 관리, 관개농업, 국제개발협력/

Bolivia. Water Resource Management, Irrigate Agriculture, International Development Cooperation

\section{Abstract}

This thesis aims to develop a potential issue which is the very possible to cooperate internationally with the ODA development strategy between Korea and Latin America, particularly in Bolivia in the parts of water resource management and irrigation agriculture. By recognizing these parts as important international development issues, this thesis scrutinizes the current situations and problems for more cooperation each other in the dimension of agricultural and economic development. Traditionally and currently, the economic growth of this region has been strongly depend on the agricultural development. On this reason, this region has developed this sector with investment and industrial policies during the 20th century. However, the way of traditional development methods has confronted many problems and are vulnerable with the changed circumstances such as in the fields of agricultural productivity, efficient agricultural system, institutional improvement related basically with water management and irrigation agriculture, which 
means, the old system does not guarantee the sustainable development model without considering water management. The targeted countries such as Bolivia, Paraguy, Peru and Guatemala in Latin American region, now they strongly demand an international cooperation in this part and it increases development projects by international cooperation agencies such as IDB, World Bank, etc.

This thesis analyses about this tendency and develop more necessary cooperation in the parts of water management and irrigate agricultural system, which are basic tools in the building of the SOC. Chapter 2 and 3 thus argue that it is necessary for guide-line to cooperate each other in details followed:

First. to provide international development and its cooperate into this part, it is helpful to put public finances in a healthy and sustainable position especially in the investment of water management and poverty reduction. Secondly, as basic reason, it protects water resource as environmental goods and third in the filed of sanitation matter and in the dimension of role, it could develop the capacity of government management skills, this could protect and save water resource as an important public goods. The water as a public goods plays a great role to deliver universal service and function poverty reduction as well. In addition, the efficient water management and development of irrigate agricultural system, it helps to reduce the global warming, confronting with climate change in the processes of climate change adaptation and response. it also provides job creation with development of agricultural industry which could reduce the rural poor. finally, the cooperation and international investment this part, it will harmonize the social conflict which might take place in the process of management of water resource(tax regime, institutions) between central and local governments and among rural and indigenous communities such as water war in Bolivia in the early of 21 th century.

\section{I. 들어가며}

유엔(UN) '천년개발목표(이하 MDGs)'의 인도주의를 통한 빈국에 국제원조라는 기본 목적의 충족 과 더불어 오늘날 많은 선진국들은 자국의 정치경제적 국익이 최대한 반영되는 전략으로 공적개발원 조(이하 $\mathrm{ODA}$ )사업을 활용하고 있다. 사실 국제원조는 2 차 세계대전 이후 동서냉전 시대에 접어들어 공산 세력의 국제적 헤게모니 확장을 염려한 미국의 전략적 필요에 의해서 시작되었다고 볼 수 있다. 중남미 지역의 경우 1959 년 ‘쿠바혁명' 이후 중남미 지역에서 좌파세력의 확장을 미연에 방지하고자 했던 미국 케네디 정권의 '진보를 위한 동맹(Alliance for Progress)'은 이러한 국제원조의 중요한 사 
례로 평가받고 있을 정도이다. 그리고 오늘날 2000년대에 들어와 유엔이 채택한 'MDGs'가 국제사회 의 주요의제로 인식되면서 개발이 국제원조의 중심이 되었다.1) 선진 공여국들은 MDGs 달성에 뒤쳐 져 있는 빈곤국들(아시아, 아프리카 및 라틴아메리카 지역)에 대한 ODA의 확대를 통해 빈곤퇴치에 기여하고 이들 지역의 경제 및 사회 발전을 이루겠다는 의지 아래 수많은 ODA사업을 확장해 내고 있 다. 2008 년 기준 전체인구의 3 분의 1 이 하루 생활비 2 달러 이하의 빈곤상태에 놓여 있는 라틴아메리 카 지역은 특히 이에 해당한다. 21 세기 들어 비록 여타 아프리카 와 아시아 국가들에 비해 상대적으 로 괄목할만한 경제성장을 이루어내고 교육, 기초보건 등의 개발지표(Development Index; DI)에서 양호한 성적을 내고 있기는 하지만 여전히 빈곤, 사회소득불평등, 저발전된 민주주의, 마약문제, 부 정부패, 수많은 질병과 전염병(특히 AIDS), 환경오염 등 많은 정치경제 및 경제사회적 문제점에 노 출되어 있으며 다양한 개발과제를 안고 있다. 국제사회의 관심과 지원이 지속적으로 필요한 지역의 하나이다.

한국은 21 세기 들어 에너지외교의 일환으로 석유, 천연가스 등 천연자원을 다량 보유하고 있는 라 틴아메리카 지역에 대한 관심도가 크게 늘었다. 이에 따라 한국정부는 2008-2010년 사이 라틴아메 리카 지역에 대한 무상원조규모를 $\mathrm{ODA}$ 의 $15 \%$ 선까지 끌어올리겠다고 밝힌 바 있다. ${ }^{2}$ 원조 형태를 자세히 살펴보면 한국은 지난 20년간 신흥 공여국으로서 라틴아메리카 지역에 대한 인프라 건설, 물 자지원, 기술협력 그리고 재난구호 등 다양한 원조를 제공해 왔고 사업발굴과 추진에 있어서도 수원 국의 '필요(Needs)'를 적극 반영하여 원조의 효율성을 증대시켜 오고 있다. 핵심원조 분야인 '빈곤퇴 치, 교육, 보건 및 의료, 정보통신, 민주주의와 거버넌스 시스템 구축, 양성평등과 여성의 권리보호, 환경보호, 자연재해, 마약, 조직범죄 및 분쟁 예방과 해결 등에 개발 역점 과제를 두고 사업을 확장 시켜오고 있다(이현주 2008:11). 물론 지나치게 많은 협력분야 때문에 각 사업별 명확한 목표와 정책 가이드라인이 아직 잡혀 있지 않아 체계적인 전략의 부재 속에서 산발적으로 추진되고 있다는 비판 도 존재한다. 특히 라틴아메리카 지역에 가장 많은 ODA사업을 추진 중에 있는 미국, 스페인, 일본, 스웨덴, 독일의 경우와 비교하여 전략적인 '선택과 집중'이 부족하거나 새로운 사업 발굴에 다소 늦 게 대처한다는 비난을 받고 있기도 하다.

1) 공적개발원조(Official Development Assistance: ODA)로 대표되는 국제원조는 인간안보 확보를 위한 대표적 노력들 중 의 하나이며, 2차 세계대전 이후 선진국에서 후진국으로의 다양한 지원이 이루어져 왔다. 이후 2000년 9월 UN 밀레니엄 정상회의(Millennium Summit)에서 인류의 평화, 인간안보, 개발, 인권, 자유를 위해 국제사회가 공동 노력을 기울이자는 '밀레니엄 선언문'이 채택됨으로써 더욱 구체화되었다. 특히 대외원조의 실행에 있어 수원국의 시각에서 '공포와 결핍으 로부터의 자유(free from fear and want)'를 위해 무엇이 필요한지를 고려하고, 개도국의 요구(Needs)를 보다 적극적으 로 수용함으로써 인류의 공동 발전과 평화를 이룩하는 쪽으로 정책방향이 재구축되어야 한다는 점이 강조되고 있다.

2) 2000년대 이후 최근 10년간 중남미 원조가 우리나라 양자 간 무상 ODA 총액의 5-6\%선에 불과했다. 하지만 최근 정부 의 보고대로 2015년 GNI대비 ODA규모가 정부 계획대로 현행 $0.07 \%$ 에서 $0.25 \%$ 로 늘어나면, 전체 ODA의 규모는 연 간 33억 달러로 증가가 예상되고 이에 따라 중남미 양자 간 무상원조 규모도 약 2. 56억 달러로 증가할 계획이다. 
본 논문은 위와 같은 비판들을 수용하면서 향후 21 세기 한국의 대(對)라틴아메리카 국제개발협력 (ODA)사업 진출 중에 잠재성이 뛰어난 이 지역 개도국들의 수자원 관리 및 이를 통한 농업발전 - 예 를 들어, 관개농업 분야를 새로운 개발협력 분야로 인식하고 이에 대한 협력 가능성 전망을 모색해 보고자 한다. 이러한 인식은 라틴아메리카 개도국들이 전통적으로 농업발전을 통해 경제발전을 추구 해 온 지정학적 그리고 경제적 특징을 고려해 협력 대상과 이슈를 고려했다. 지난 20세기 동안 전통 적인 수출 상품으로써 개별 국가들의 경제성장에 지대한 영향을 미치고 있는 농업 분야에 대한 개발 과 협력은 사실 오늘날 많은 발전을 해 오고 있다. 하지만 이러한 발전은 21세기에 들어와 농업 생산 성 향상, 농업 시스템과 제도적 개선 등에서 여전히 취약하며 지속가능발전 차원에서 많은 한계를 지 니고 있다. 특히 개발원조 핵심 대상 국가들로 떠 오른 빈곤 국가들(볼리비아, 파라과이, 페루, 과테 말라 등)의 경우에도 이 분야에 대한 수요국의 필요와 요청이 증가하고 있는 추세이다.

이러한 추세와 경향들을 고려해 새로운 개발협력분야로 상정 가능한 라틴아메리카 지역에서의 21 세기형 농업분야 발전과 밀접하게 연관된 수자원 관리 분야에 대한 국제개발협력을 진단해 보겠다. 본 논문이 대상으로 하는 국가는 볼리비아이다. 볼리비아와의 개발협력 관점에서 현재 이 국가가 직 면하고 있는 수자원 관리위기 및 이와 관련한 다양한 관개농업 위기 상황들을 인식하고 이를 바탕으 로 이 분야들에 대한 향후 개발협력 가능성을 분석해 보고자 한다. 수자원 관리 분야 국제개발협력의 시대적 필요성은 오늘날 라틴아메리카 지역의 통합적 수자원 관리 부문 개발과 관련해 세계은행과 국제기구들 및 개별 선진공여국가들의 적극적인 참여를 통해 확인해 볼 수 있다(제 2 장 4 및 제 3 장 6). 특히 수자원 관리 및 관개농업 시스템 구축 분야에서 국제협력이 강화되고 있는데 이는 다음과 같은 주요 요인들을 통해서 그 방향과 구체적인 국제협력 목표들이 설정되고 있다.

첫째, 라틴아메리카 지역의 재정건전화와 빈곤감축을 들 수 있다. 오늘날 국제기구의 하나인 IMF는 '빈곤소멸과 성장촉진(Poverty Reduction and Growth Facility: PRGF)'이라는 프로그램을 통해 개발 도상국의 수자원 관리 분야에 민간기업의 참여를 적극적으로 추진하고 있으며, 이러한 국제적 움직임 은 1989년 '브래디 플랜(Brady Plan)'에 민간참여를 통한 공공부문의 개혁추진에 의해 더욱 구체화 되 었다. ${ }^{3)}$ 또한 세계은행의 경우는 신규융자와 채무삭감의 조건으로 수자원 관리(특히, 수도 사업 및 관 개농업)를 독려해 오고 있다. 둘째, 무분별한 수자원 관리 및 개발에 의한 수자원 보호를 들 수 있다. 세 계은행은 1993년 '수자원 개발전략'을 통해 수자원 관리와 개발이 지속적 성장과 빈곤해결에 있어 중요

3) 브래디 플랜(Brady Plan)은 미국 재무장관인 브래디(Nicolas Brady)가 1989년 발표한 개발도상국의 채무구제방안으로, 개도국의 경제성장과 외채상환능력의 배양을 위해 신규차관 공여에 중점을 두었던 베이커 플랜(Baker Plan)이 개도국 의 외채문제를 해결하지 못하고 1982년에 이어 1987년에 또다시 외채위기가 발발하자 그 대안으로 제시되었다. 브래 디는 개도국의 외채위기를 '상환불능의 위기'로 파악하고 채무국인 개도국의 과도한 외채원리금을 그 국가의 구조조정 노력 정도에 따라 탕감해 줄 것과 IMF 및 세계은행의 역할을 제고할 것, 그리고 외채를 민간투자로 전환하는 계획 (swap)등을 주장했다(이성형 2001:163). 
하며, 국가협력전략(CPS)과 빈곤해소 전략에 있어 중점적으로 추진해야할 사안이라고 밝히고 있다. ${ }^{4)}$ 셋째, 물과 위생분야에 있어 개도국 정부의 관리능력의 회복에 도움을 줄 수 있다. 특히 거액의 초 기투자를 필요로 하는 수자원 관리 - 예를 들어, 상하수도 사업 및 위생시설 등의 경우 - 개발도상 국 정부가 충분한 자금을 확보하기가 곤란하다는 점에서 자금 확보를 위해 차관도입과 채권발행 등 채무증가로 이어지고 결과적으로는 서비스 질이 악화되는 부분에 국제개발협력이 절실히 필요하다. 넷째, '공공재(Public Goods)'로서의 기능 회복과 효율적인 공급을 들 수 있다. 수자원 관리 및 개발 은 지속적 성장과 빈곤 해소를 위해 중요한 분야임에도 불구하고 개발도상국의 경우 '보편적 서비스 (Universal Service)'에서 소외되는 계층이 확대됨으로써 공공재의 기능을 회복시키기 위해서는 풍 부한 경험과 능력을 보유한 해외 개발협력체들이 참여함으로써 서비스의 질과 공공성을 확보할 수 있다. 특히 국제기구 및 일반 사적기업들의 참여를 통해 경쟁이 도입됨으로써 인프라 시설 개선의 효 과를 가져올 수 있으며, 빈곤층의 선택지가 확대됨으로써 결과적으로는 정부의 재정 경감과 함께 기 업의 이익을 추구할 수 있다는 이점이 있다. ${ }^{5)}$

다섯째, 수자원 분야 관리를 통한 기후변화에 대한 대응과 적응의 차원에서 살펴볼 수 있다. 효율 적인 수자원 관리는 결국 급속한 기후변화를 완화하고 지속가능한 발전의 중심이 되기 때문이다. 여 섯째, 특히 관개농업 분야에서 수자원 관리는 농업 국가의 특징을 보이는 이들 개발도상국들에게 농 업생산성 확대는 물론 농촌 공동체들의 일자리창출과 농가 소득의 증대에 영향을 미쳐 농촌 빈곤을 어느 정도 해소해 줄 수 있는 장점이 있다. 마지막으로 효율적인 수자원 관리는 중앙정부와 지방 그 리고 수자원 공급자와 수급자 사이에 발생할 수 있는 다양한 사회적 갈등을 해소해 장기적인 차원에 서 사회통합을 도모할 수 있는 장점이 있기도 하다(Box 1, 볼리비아의 ‘물 전쟁’ 참조).

특히 남미의 볼리비아 경우는 지속가능한 농업발전과 개발의 필요성을 우선으로 현실 가능한 협력 방안을 모색해 보는 대안으로 위와 같은 수자원 관리 및 관개농업에 개발 절박성이 있다. 본 논문은 이러한 개발 절박성의 상황을 진단해 보고 구체적인 개발협력 분야를 살펴보기 위한 목적으로 구상 되었다. 이를 위해 볼리비아의 오늘날 수자원 관리 및 이와 관련한 관개농업 분야의 현재 상황과 개 발협력의 필요성을 구체적인 데이터들을 통해서 진단해 보고자 한다. 위에서 언급한 다양한 시각의 분석과 이에 대한 진단 및 평가를 통해 향후 국제개발협력의 다양한 가능성을 탐색해 보겠다. 이런 인식을 토대로 제 2 장에서는 볼리비아의 수자원 관리 전반에 대한 현황과 제도적 문제점 그리고 협 력이 필요한 부문에 대한 향후 전망 등에 대해서 살펴보며, 제 3장에서는 볼리비아의 관개농업 현황 과 농업발전과의 상관관계 분석을 통해 개발협력의 필요성을 제기해 본다. 특히 이 장에서는 볼리비 아 9 개 주에 달하는 지역적 특성들과 관개농업의 개발 정도 및 관개 수자원 관리 차원의 문제점 그리

4) (World Bank 2003: 6 8).

5) (World Bank 2002:1 5). 
고 이의 다양한 분야(농업, 환경 및 농촌 빈곤)에 대한 현황들을 살펴본다.6) 제 4장에서는 결론으로 전체 내용을 요약 및 정리하며 좀 더 한국의 입장에서 구체적으로 협력이 가능한 국제협력 방향을 제 시하고 시사점을 도출해 본다. ${ }^{7)}$

볼리비아는 풍부한 천연자원을 통한 광산 활동과 석유 및 천연가스 자원, 혹은 리듐 자원의 보고 로 알려져 있는 남미 지역에 위치한 내륙 국가이지만, 전형적인 농업 국가이다. 볼리비아 농업발전을 위한 혹은 농업생산이 가능한 토지는 전 면적 $(1,084 \mathrm{~km} 2)$ 에서 $34 \%$ 에 해당한다. 하지만 이 중에서도 관개농업시스템이 갖추어 진 상태로 경작이 가능한 면적은 2010년 통계로 단지 3.9\%에 지나지 않는 다. 관개시스템이 들어선 토지 면적이 226,500 헥타르(ha)에 지나지 않고 있다. 관개시스템도 지표 수를 이용한 관개시설이 갖추어진 면적은 128,000 헥타르(ha)이고 스프링클러 관개방식은 300 헥타 르(ha)에 머물고 있다. 2000년-2004년 동안 통계를 기준으로 보면 관개농업 방식을 통한 농업생산 은 볼리비아 GDP에서 약 $14 \%$ 정도를 차지하고 있다. ${ }^{8)}$

전통적인 농업 국가로서 특징을 살려 볼리비아 정부는 자국의 농업발전을 위한 일환으로 이러한 열악한 상태의 관개농업시스템의 전환을 통해 농촌 지역의 삶의 질을 개선시키고 농촌 공동체들의 향후 발전은 물론, 장기적인 차원에서 볼리비아 농업생산 구조를 개선하고 및 이를 통한 경제발전 및 성장이라는 시너지 효과 창출을 위해 노력을 하고 있다. 이러한 인식의 전환은 특히 국가의 수자원 공급 방식에서 민영화 방식을 선택한 이후 오랫동안 지속된 수도 '라 파즈(La Paz)'와 '코차밤바 (Cochabamba)' 지역의 대규모 사회적 저항(일명 '물 전쟁')이 계기가 되었다. 이후 볼리비아 정부는 이러한 수자원 공급 방식의 잘못을 정부 책임으로 인정하고 대대적인 제도적 개혁을 통해 특히 관개 농업 부문에서 효율적인 수자원 관리를 약속했다. 예를 들어, 기존에는 몇몇 국가 정부 엘리트들에 의해 혹은 다국적 기업을 중심으로 관리되어 왔던 수자원 정책에 대한 지역의 농촌 공동체 및 원주민 공동체들의 적극적인 의사결정 참여, 수자원 및 관개시스템 관리에서 전통적인 방식과 새로운 기술 통합, 수자원 이용에 관한 소비자 권리 인정과 등록제 허용, 관개 인프라의 효율성 증진, 수질의 강 화, 이 분야 시스템 개선을 위한 정부의 필요 투자 확대 및 재정의 지속적이고 안정적인 투자 등에서 향후 볼리비아 수자원 정책 변화의 우선사항들로 고려했다. 제도적으로도 볼리비아는 여타 남미국가 들과 비교해 수자원 및 관개농업 분야 관리에 대한 중요성을 부여해 처음으로 '수자원 부(Water Ministry'를 두고 이를 통합적으로 관리한다고 발표했다.

6) 볼리비아 농업 관련 정보와 데이터는 주로 볼리비아 국가개황 및 유엔식량농업기구, 볼리비아 수자원 부 자료들을 인용 참조함.

7) 본 논문은 따라서 오늘날 한국의 대중남미 개발협력 대상국으로 등장한 볼리비아(페루, 파라과이, 에콰도르와 더불어) 에 대한 개발협력 분야에서 농업발전 및 경제발전에서 가장 시급하게 협력이 요구되는 볼리비아의 수자원 관리 및 관개 농업 분야에 대한 접근이다. 볼리비아의 수자원 관리 시스템과 관개농업 분야의 일반상황 분석과 이 분야에 대한 다양 한 개발협력의 필요성을 중심으로 고찰함.

8) 물세(Tariff): 입방미터 당 0.05 달러(0.05 US\$/m3). 


\section{II. 볼리비아 수자원 현황 및 수자원 관리}

오늘날 볼리비아의 수자원 이용을 부문별로 고찰해 보면, 일반가정용으로 $12 \%$, 농업용으로 $82 \%$ 그리고 산업용으로 $6 \%$ 이용도를 보이고 있다. 전통적으로 볼리비아는 수자원 관리에서 여타 다른 나 라들과는 달리 지정학적인 차원을 고려해 정치적 혹은 제도적 불안정을 극복하기 위한 목표를 두고 수자원 관리 접근 방식을 보여 왔다. 특히 2000-2006년 사이 볼리비아의 코차밤바나 엘 알토(El Alto) 지역에서 발생한 이른바 '물 전쟁'은 사회적 저항 및 갈등으로 나타나 수자원 관리가 볼리비아 에서 얼마나 힘든 문제인지를 보여준다. 이와 더불어 볼리비아의 위생시설 서비스 제공에 대한 문제 도 볼리비아 정부가 향후 공공재 서비스 제공 과정에서 어떻게 할 것인지에 대한 논의도 포함되었다 (Box 1 참조).9) 2008년 볼리비아 정부가 마련한 향후 수자원 관리와 위생시설 서비스 향상 목표는 2015년까지 볼리비아 국민의 90\%에게 수자원 접근을 허용하며 $80 \%$ 까지 위생서비스 접근이 가능하 도록 한다는 계획을 가지고 있다. 이러한 목표 달성을 위한 재원은 연간 약 2 억 9 천만 달러가 소요될 것이며 이러한 수치는 오수의 재사용에 대한 기술적 투자와 기후변화 적응에 대한 투자도 포함되어 있다. ${ }^{10)}$

\section{〈Box 1〉볼리비아의 '물 전쟁'}

1997-2001년 사이 집권한 볼리비아의 우고 반세르(Hugo Banzer) 정부는 1999년 수자원 관리 분야에 대한 정책 및 제도 개혁을 위해 '부문별 기구 체계법(법률 2029)'을 통과시켰다. 이러한 제 도개혁을 통해 수자원 관리 분야에 민간 부문의 참여가 허용되었고 이를 규제할 기구로 1997년 만 든 '물 감독청(Superintendencia de Agua)'을 대신하여 '기초위생 감독청(SISAB Superintendencia de Saneamiento B sico; SISAB)'을 재조직했다. 이러한 법적 제도적 개혁을 통해 두 가지 분야 에 대한 볼리비아 정부는 수자원 관리에 대한 민간참여 및 민영화를 허용했다. 하나는 1997년 수 도인 라 파즈와 엘 알토 지역에 프랑스 수에즈사의 자회사인 '일리마니 물 회사(Aguas de Illimani

9) 2010년 현재 개발도상국의 인구 중 20억 명이 위생시설 서비스에 접근하지 못하는 것으로 파악되고 있다. 유엔(UN)은 2015년까지 'MDGs' 차원에서 이를 개선 사항으로 두고 있다. 이러한 목표를 달성하기 위해서는 연간 투자액이 140억 달러가 필요하다고 전망하고 있다. 하지만 간이하수처리 기술을 이용한 위생시설 향상은 이 투자액을 $50 \%$ 정도 절감할 수 있다고 보고 있다.

10) 간이 하수처리(Simplified Sewage Treatment)에는 간이 처리, 중급 처리, 고급 처리의 3종류가 있다. 간이 처리로는 하수중의 미립자, 용해성 물질 및 세균의 제거가 불가능하므로 중급 처리 및 고급 처리의 전처리로서 행해지는 경우가 많다. 간이 처리시설로서는 침사지, 부사 저지판, 유지 저지판, 스크린 등이 있다(화학물질정보 사이트 인용: http://www.nier.go.kr). 현재 간이하수처리 기술을 이용한 위생시설 접근 허용한 개발도상국은 라틴아메리카 지역에 서 볼리비아(엘 알토 지역에서 파일럿 프로젝트), 온두라스의 테구시갈빠(Tegucigalpa)의 빈곤 지역, 페루 리마의 주 변 빈곤 지역 등에서 활용되고 있다. 
S.A.; AISA)'에 민영화를 허용했고, 그리고 1999년 코차밤바 주에 다국적 물기업인 바이워터사 (Biwater)와 베체사(Bechtel)사의 자회사인 투나리 물 회사(Aguas de Tunari)에 민영화를 허용했 다. 이러한 수자원 민영화에 반발하는 대규모의 사회 저항 운동이 2000년 4월 코차밤바에서 시작 되었고 2005년 1월에는 라 파즈와 엘 알토 지역으로 확산되었다. 2008년 결국 이러한 물 민영화는 '일리마니 물 회사(Aguas de Illimani S.A.; AISA)'의 경우, 물 부족, 회계실수, 물세인상, 서비스 부 족 등의 이유로 비난을 받으며 민영화가 철회되었고 이와 동시에 공공 기관인 엡사스(Empresa P blica Social de Agua y Saneamiento; EPSAS)의 관리 하에 들어갔다. 결론적으로 라 파즈의 수자 원 관리 이해당사자(수자원협회 등)들은 독립적인 서비스 공급자를 창출한 셈이다.

볼리비아의 하수 오물 및 위생시설에 대한 디자인과 건설에 대한 사항을 규정하고 있는 기술적 규범 688 조는 2001년 들어 개정되었다. 저비용으로 효율성이 고려된 '간이하수처리(Simplified Sewage System, 브라질에서 활성화된 시스템으로 일명 'condominial' sewerage systems)'방식 으로 전환을 시도하고 있다. 게다가 볼리비아 정부는 2001-2010년 사이 기초위생 국가계획을 통 해 수질 향상과 위생시설 서비스를 강화한다는 구체적인 전략을 내 놓았다. 2006년 대통령에 당 선된 '마스당(MAS)'의 모랄레스 정부는 수자원이 단지 사적 부문의 비즈니스 대상이 아니라 공공 재이며 그동안의 수자원 민영화는 볼리비아 시민들의 수자원 이용권을 심각하게 훼손해 인권 침 해까지 행했다고 비판했다. 이를 개선하기 위해 정부 차원의 독립적 관리 기구인 수자원 부를 두 고 이의 수장으로 당시 일리마니 물회사에 저항해 엘 알토 지역에서 강력한 사회저항 운동을 주도 한 지도자를 첫 번째 장관으로 임명하는가 하면 차관으로 코차밤바 저항 시위 지도자인 루이스 산 체스 고메즈 쿠케레야(Luis Sánchez-Gómez Cuquerella)를 지명하는 등 파격을 보였다.

\section{1. 수자원 관리 현황}

역사적 발전 과정에서 보면 볼리비아의 수자원 관리는 20세기 초반인 1906년 입법된 '물 일반법 (Ley General de Aguas)'에 정책적으로 의존해 왔다. 이 법에 의하면 수자원은 공공재이며 수자원의 관리 권한은 볼리비아 정부에 있고 모든 책임도 정부에 일임되어 있다. 하지만 초창기의 수자원 권리 에 대한 정의는 상당히 모호한 것이었다. 예를 들어, '토지를 통과하는 수자원의 소유권은 다른 이들 에게 영향을 미치지 않는 한 토지 소유자에게 있다' 로 규정되어 있었으며 지하수에 관한 재산권과 물이용 요금체계에 대해서는 어떠한 언급도 없었다. 이 수자원 법은 1945년 들어 최소한의 범위에서 개정되었는데 예를 들어, 좀 더 구체적으로 '하류 지역 수자원 이용자들에게 물에 대한 접근을 부정 할 수 없다'와 같은 조항들이 첨가되었다. 1988년에 이르러서는 지하수와 같은 수자원의 권리를 공공 영역에 포함시키거나 관개농업 인프라 개선으로 혜택을 받고 있던 지역의 농민들에게 물세를 부과할 
수 있다는 등의 조항들을 볼리비아 상원이 입법 수정을 하려는 시도도 있었다. 또한 이와 비슷한 시 도로 1995-1999 사이 세계은행과 독일의 국제개발협력기구인 GTZ과 더불어 볼리비아 정부는 기존 수자원 법을 근본적으로 수정하여 1988년 수정을 예고했던 수정안들을 토대로 새로운 규정과 제도적 프레임 변경 그리고 이용자들의 수자원 권리 허용 등을 포함하는 제도 개선을 시도한 바가 잇다. 하 지만 이러한 수정법안들은 새로운 수자원 법으로 개정되지 않았다. 시기를 두고 장기적인 차원의 수 자원 법 개정 논의는 하나의 통합적 차원의 법안 창출이었으나 그 내부를 살펴보면 수자원 이용을 둘 러싸고 서로 다른 분야에서 다른 법안 적용이 복잡하게 연결되어 있다. 예를 들어, 전력법, 탄화수소 법, 광산법, 환경법들에서 수자원에 대한 규정들이 각기 다르게 관리되거나 명시되어 있었다. 이러한 다양한 법들 속에서 다르게 정의되고 규정되어 있어 보다 일원적으로 통합적 차원의 수자원에 대한 관리와 제도적 규율을 어렵게 하는 원인이 되고 있었으며 수자원의 질과 양은 물론 중장기적인 차원 에서 수자원 관리에 어려움을 주었다. 이와 더불어 수자원 이용에 대한 문제도 심각하다. ${ }^{11)}$

\section{〈그림 1〉볼리비아의 수역 구분}

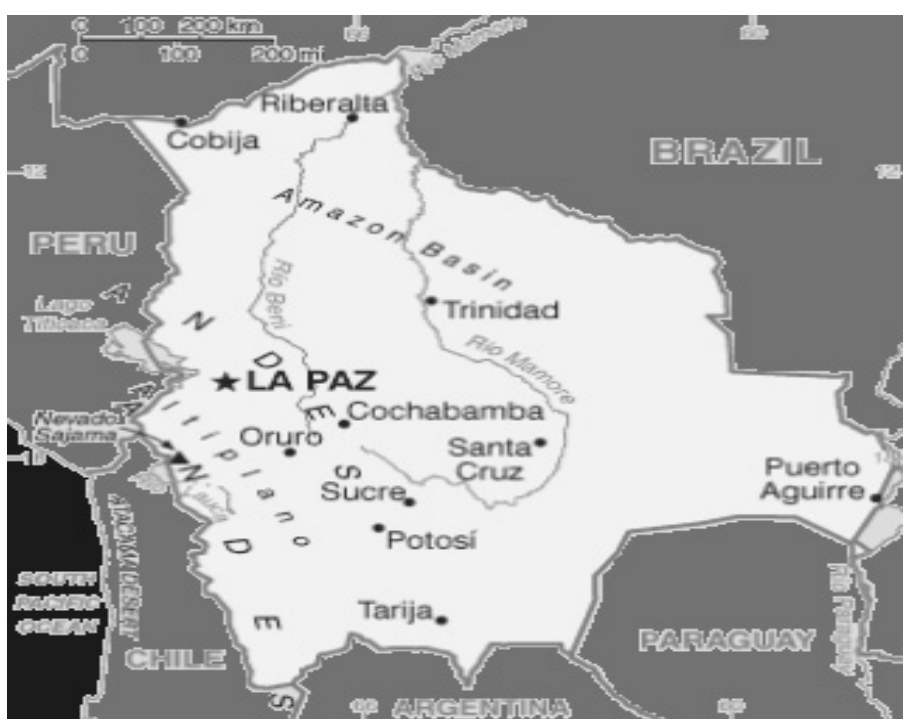

출처: CIA World Factbook 인용 및 재구성(2010).

〈그림 1〉에서 보듯이 볼리비아의 수계는 볼리비아 국토를 중심으로 내부 타원 형태로 연결 발달해 있다. 특히 〈그림 2〉에서 보듯이 이러한 수계들 중에 아마존 유역 수계는 볼리비아 수자원에서 중요 한 역할을 하고 있다(724,000 km² 로 전 국토에서 66\%). 리오 플라타(Rio Plata)유역은 아마존 수 계 다음으로 $229,500 \mathrm{~km}^{2}$ 로 $21 \%$ 를 차지하고 있다. 좀 더 상세하게 아마존 유역과 연결된 수역을 살

11 ) 볼리비아와 비교되는 여타 다른 지역(유럽, 한국)의 수자원 관리 패러다임 변화는 최동진(2010)을 참조할 것. 특히 한 국의 수자원 관리정책, 농업용수, 수도 사업, 유역통합관리 분야에 대해 비교 분석 참조. 
펴보면〈그림 2〉 및〈표 1〉과 같다.

〈그림 2〉아마존 유역의 수계(볼리비아 포함)

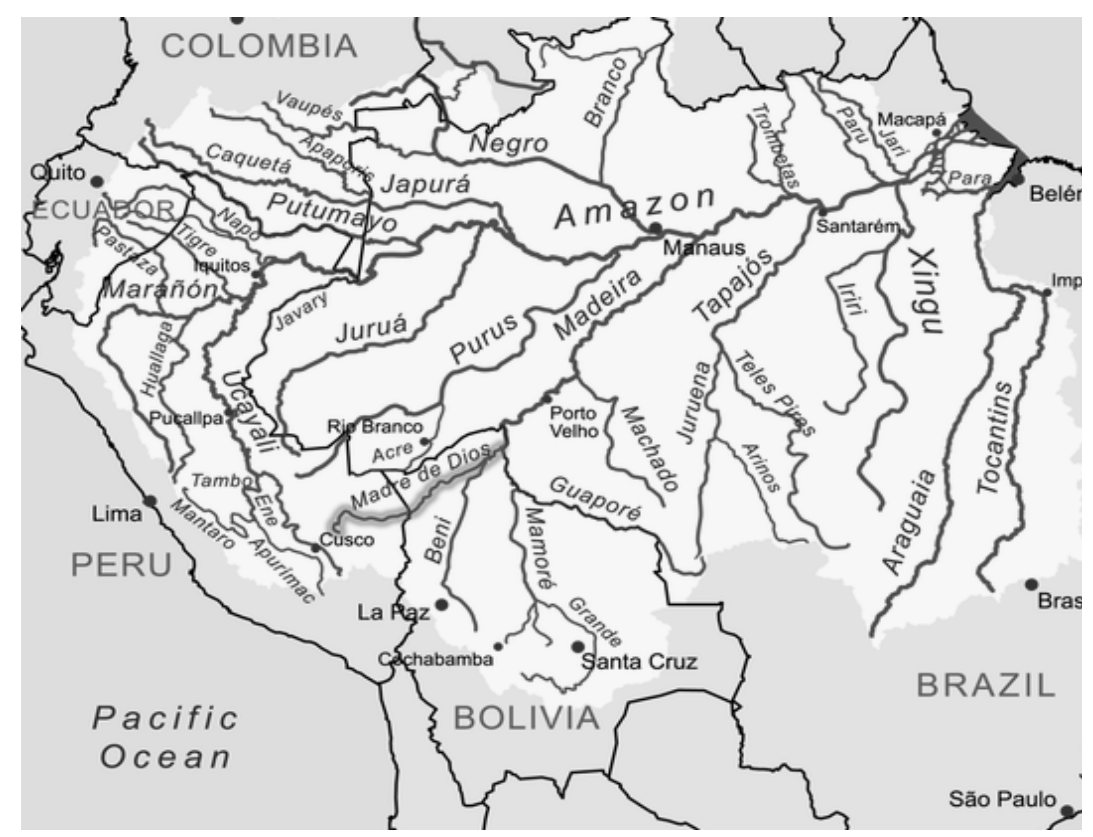

출처: CIA World Factbook 인용 및 재구성(2010)

아마존 유역의 경우는 수량이 풍부해 홍수의 피해를 내기도 하는 특징을 가지고 있다. 수계를 강 유역 별로 구분하여 수량을 살펴보면 다음과 같다. ${ }^{12)}$

〈표 1〉 볼리비아 강 유역에 따른 유량 비교

\begin{tabular}{|c|c|c|c|}
\hline 강 유역 & 주요 강 & $\begin{array}{c}\text { 지표면 } \\
\left(1000 \mathrm{~km}^{2}\right)\end{array}$ & $\begin{array}{c}\text { 평균 } \\
\text { 유량 }\left(\mathrm{km}^{3} / \text { year }\right)\end{array}$ \\
\hline 아마존 강 유역 & $\begin{array}{l}\text { 마드레 데 디오스(Madre de Dios), 오르손(Orthon), } \\
\text { 아부나(Abuna), 베니(Beni), 그란데(Grande), } \\
\text { 마모레 이테네스(Mamoré e Itenez) }\end{array}$ & 887 & 572 \\
\hline $\begin{array}{c}\text { 플라타 강 유역 } \\
\text { (Rio Plata) }\end{array}$ & $\begin{array}{l}\text { 필코마요(Pilcomayo), 베르메호(Bermejo), } \\
\text { 산후안(San Juan), 파라과이(Paraguay) }\end{array}$ & 234 & 47.5 \\
\hline $\begin{array}{l}\text { 알티플라노 } \\
\text { (Altiplano) }\end{array}$ & $\begin{array}{l}\text { 데사구아데로(Desaguadero), } \\
\text { 티티카카호수(Lake Titicaca), 푸우포(Poopó), } \\
\text { 살라레스 데 우유니(Salares de Uyuni), } \\
\text { 코이파사(Coipasa) }\end{array}$ & 191 & 14.7 \\
\hline
\end{tabular}

12) 유엔식량농업기구(http://unw.fao.org/)의 보고에 의하면 2009년 현재 볼리비아는 5개 정도의 댐을 통해 수력발전으로 이용 중에 있다. 
출처: 유엔식량농업기구(FAO; Food and Agriculture Organization 2009)

수자원 이용과 더불어 발생하는 환경오염의 문제는 볼리비아에서 심각하게 점증하는 현상이다. 수 질의 오염은 급속도로 증가해 왔다. 예를 들어, 안데스 지역의 강들에서는 높은 정도의 유기물질 (organic material)들이 포함되어 흐르고 있고 이 양은 리터당 100 밀리그램을 상회한다. 이 수자원 들은 이후 하류 지역에서 농업 관개용수로 이용된다. 아마존 유역에서는 상류에서 토지 이용과 토양 의 침식 혹은 광산 활동으로 인하여 수질이 악화되는데 이는 물에 침전물들이 집중되어 발생하고 있 는 현상이기도 하다. 산림과 농업 활동은 또한 볼리비아의 수자원과 수질에 악영향을 미치고 있다. 볼리비아 농업 활동에서 중요한 사탕수수 생산 활동의 경우는 산타 크루즈 주에 위치한 피라이 강 (Rio Pirai) 유역에서 어업 활동을 불가능하게 하는 것으로 보고되고 있기도 하다. ${ }^{13)}$

\section{2. 수자원 관리와 기후변화 영향}

수자원 관리에서 가장 중요한 또 하나의 사항은 자연 재해로부터 피해를 줄이는 일이다. 볼리비아 에서 빈번하게 자연재해로 발생하는 현상은 우기에 볼리비아 지역 전반에서 광범위하게 발생하는 홍 수와 산사태 피해이다. 물론 이러한 자연피해는 볼리비아 수계 및 수자원 관리에도 악영향을 미친다. 게다가 이러한 자연재해는 2000년대 들어 기후변화와 관련한 현상과 더불어 그 피해는 기하급수적 으로 증가하고 있다. 라틴아메리카 지역의 기후변화를 대표하는 엘 니뇨 및 라 니냐 (El Niño/La $\mathrm{Niña)현상들과} \mathrm{밀접한} \mathrm{관계를} \mathrm{맺고} \mathrm{있기} \mathrm{때문이다.} \mathrm{이러한} \mathrm{기후변화는} \mathrm{수자원과} \mathrm{관련된} \mathrm{수많은} \mathrm{자연}$ 재해를 발생시키고 있는데 예를 들어, 2002년 포토시 지방에서는 역사적으로 유례가 없는 폭설과 폭 풍의 피해라든지, 수도인 라 파즈 지역의 파괴적인 우박의 피해, 2004년 차코 지역의 장기간에 걸친 가뭄으로 인한 산타 쿠르즈(Santa Cruz), 추키사카(Chuquisaca) 그리고 타리하(Tarija) 지역 거주민 약 20 만 명 $(15 \%$ 가 아동인구)의 식량 안보 및 건강과 영양 상태 위협 등의 재해들이 일어났다. 2006-2007년 사이 발생한 볼리비아의 엘니뇨현상은 볼리비아 경제 성장율의 $4 \%$ 에 달하는 경제적 피해를 입혔으며 13 만 가구 혹은 거의 60만 명의 일상에 피해를 주었으며 이는 1997-1998년 엘니 뇨현상 피해의 5 배에 달하는 수치로 계산된다. 더욱 심각한 것은 이러한 피해가 발생한 지역이 거의 농촌 지역이라는 사실이다. 2007-2008년 라니냐로 인한 자연재해는 이전 보다 그 피해가 $20 \%$ 정도 늘어났으며 경제적 규모로는 500 만 달러 이상의 피해와 12 만 이상의 가구 피해를 결과로 발생시켰 다. 이 피해가 집중적으로 발생한 지역은 농촌지역으로 거의 $53 \%$ 정도의 피해를 이 지역들에서 흡수 해야 했다. ${ }^{14)}$

기후변화와 관련된 좀 더 구체적인 피해 증가는 특히 수자원 관리 부문과 관련한 볼리비아 정부의 보

13) Mattos, Roger (2000). "Información Sobre la Gestión del Agua en Bolivia."

14) Ministerio de Planificacion del Desarrollo (2007). 
고서에 의하면 볼리비아의 극심한 자연재해로 인한 피해 증가 현상은 '수문기상학(hydrometeorological)' 분야에서 흔히 발생되며, 기후변화 현상을 통해 집중적으로 발생하고 있다고 보고하고 있을 정도이 다. 이미 이러한 현상은 'UN 기후변화에 관한 정부 간 협의체(UN IPCC)'에서 2001년 볼리비아 사례 를 예측한 바 있다. 2000년대 들어 볼리비아에서는 열대 폭풍이 빈번하게 발생하며 풍속이 거의 보 퍼트 풍력 단위로 $28 \mathrm{~m} / \mathrm{s}$ 이상에 달한 적도 많다. ${ }^{15)}$ 이는 엄청난 대륙성 강우를 동반해 해일 폭풍을 일으키는 주 원인이 되었고 2002-2003년 수도인 라 파즈에서 발생한 자연재해는 이러한 현상들의 증거들이었다. 가뭄 피해는 더욱 극심하다. 기후변화로 인하여 볼리비아의 건조 및 반 건조 지역 특 히 고지대에서 가뭄 현상이 더욱 빈번히 발생하고 있다. 가뭄의 피해는 비단 농촌 지역에서 뿐만 아 니라 산업 생산이 집중된 도시 지역에서 그리고 수자원 관리 시스템의 부족과 저발전으로 그 피해는 더욱 크게 증가하고 있다. 수자원 공급 시스템은 열악하며 갈수기에 수자원을 보존하는 시스템도 상 당히 낙후되어 있는 형편이다. 기후변화에 따른 홍수의 피해는 짧은 시기 동안 집중적인 강우량을 통 해 발생하며 이는 상당할 정도의 인프라 피해를 가져오고 있다. 또한 짧은 시기 동안의 강우량 집중 현상은 전반적으로 장기간의 걸친 평균 수자원 관리에도 상당히 악영향을 미치고 있다. 하지만 볼리 비아의 경우 여전히 강우량 패턴을 연구해 이를 시스템적으로 조절하는 능력은 부족한 상태이다. 물 론 기본적으로 집중적인 홍수 피해에 대한 조기경보 시스템 마련도 정책적으로 혹은 시스템적으로 잘 정비되어 있지 못하다.

게다가 볼리비아의 많은 강 유역들에서 오늘날 유역보호 차원으로 통합적인 수자원 관리 시스템 구축을 위한 많은 활동들이 전개되고 있는데 이는 환경피해는 물론 기본적으로 토양 침식, 대수층의 재충전 능력 감소, 물의 이용도 감소 현상을 불러와 경제적 생산성과 거주민들의 소득을 상당할 정도 로 떨어뜨리고 있는 원인이 되고 있기도 하다. 볼리비아의 지정학적인 위치상 안데스 산맥의 융빙 현 상은 또 다른 기후변화의 산물이다.16) 지역별로 볼리비아의 기후변화에 따른 자연재해 발생 시나리 오들을 정리해 보면 다음과 같다.

15) 보퍼트 풍속 단위는 $\mathrm{m} / \mathrm{s}$ 로 표시하는데 이는 바람의 강도를 표시하는 것이다. 계급번호가 클수록 풍속이 강하다. 현재 널리 사용되는 것은 1805 년 보퍼트가 만든 보퍼트 풍력계급을 1964 년 개정한 것이다. 0 부터 12 까지 13 개의 풍력계 급이 있으며 폭풍주의보는 풍력계급 7(13.9 17.1 m/s) 이상, 폭풍경보는 풍력계급 $9(20.8 \sim 24.4 \mathrm{~m} / \mathrm{s})$ 이상이다. 풍 속 $\mathrm{V}$ 를 $\mathrm{m} / \mathrm{s}$ 단위로 표시하면 $1 \mathrm{~m}^{2}$ 면에 대한 풍압 $\mathrm{kg}=0.125 \mathrm{~V} 2$ 으로 주어진다. 그래서 $10 \mathrm{~m} / \mathrm{s}$ 의 바람이 불 때 $1 \mathrm{~m}^{2}$ 면에 대해서는 약 $12 \mathrm{~kg}$ 의 압력을 받고 $30 \mathrm{~m} / \mathrm{s}$ 의 경우에는 $112 \mathrm{~kg}$ 의 압력을 받게 된다.

16) 'Glacier Retreat', 일명 '융빙' 현상은 빙하가 녹는 것으로 지구 온난화에 의해 발생하며 해수면을 상승시키는 결과를 초래함에 따라 대륙의 면적을 감소시키는 결과를 가져 온다. 대륙 내 산맥 정상을 차지하는 빙하의 융빙은 직접적으로 산사태를 유발하고, 홍수와 빙하 주변 호수의 범람을 가져온다. 그러나 더욱 심각한 문제는 단기적으로는 강물의 양을 증가시키나 몇 십 년 후에는 강물의 양이 급격히 감소하여 생태계를 위협한다는 것이다. 빙하는 강수량(눈)이 많은 시 기에 담수를 빙하의 형태로 저장하고 있다가, 따뜻하고 건조한 시기에는 저장한 물을 녹여서 강물로 내보내는 역할을 한다. 만약 빙하가 줄어들면, 저장된 담수의 양이 적어 강물의 양이 급격히 감소하게 된다. 볼리비아 융빙 현상 사례 는 '차칼타야 빙하(Chacaltaya Glacier)'가 대표적인데 이에 대해서는 Francou, Bernard et al.(2000) 참조. 
〈표 2〉볼리비아 지역별 기후변화 시나리오

\begin{tabular}{|c|c|}
\hline 볼리비아 주요 지역 & 기후변화 시나리오 \\
\hline 알티플라노(Altiplano) & $\begin{array}{l}\text { 점증적 강우량 증가, 짧은 시기동안 우기 및 해일 폭풍 빈번 발생, 낮은 } \\
\text { 강하천 유량 }\end{array}$ \\
\hline 안데스 계곡(Andean Valleys) & 점증적 강우량 증가, 짧은 시기동안 우기 및 해일 폭풍 빈번 발생 \\
\hline 차코(Chaco) & 장기간의 건조 시기 증가, 빈번 가뭄 현상 증가, 낮은 강하천 유량 \\
\hline 아마존유역(Amazon) & $\begin{array}{l}\text { 점증적 강우량 증가, 흐린 날 빈도수 증가, 여름철 고온 다습, 겨울철 심 } \\
\text { 한 건조기 증가 }\end{array}$ \\
\hline
\end{tabular}

출처: 볼리비아 기후변화 국가 프로그램(National Program for Climate Change 2008)

\section{3. 볼리비아의 부문별 수자원 관리}

\section{1) 식수 및 위생 분야}

볼리비아의 식수 분야와 위생 서비스 분야는 수자원 관리 분야에서 1990년대 이후 급속한 발전을 거듭해 오고 있다. 이는 각 분야별로 투자 증가가 큰 영향을 미쳤다. 하지만 볼리비아는 여전히 여타 다른 이웃 국가들과 비교하면 서비스 분야의 보급률에서 그리고 질적으로 가장 낮은 상태를 보이고 있다. 가장 낮은 보급률은 특히 판도(Pando), 포토시(Potosí) 그리고 오루로(Oruro) 지방에서 열악하 다. 하지만 수자원 공급 서비스 보급에 대한 요구는 각 지방별로 지대하게 증가하고 있다. 이는 특히 2007년 이후 그동안 증가했던 이 분야에 대한 투자가 감소하면서 공급 균형의 문제가 발생하고 있 다. 2006년까지 수자원 공급과 위생 서비스 분야 공급 상황을 보면 다음과 같다(〈표 3〉 참조).

〈표 3〉 볼리비아 수자원 공급 및 위생서비스 현황 $(\%, 2006)$

\begin{tabular}{c|c|c|c}
\hline 서비스 분야 & 도시(총인구의 64) & 농촌(총인구의 36) & 총합 \\
\hline 물공급(폭넓은 범위) & 95 & 68 & 85 \\
\hline 물공급(가정 연결) & 90 & 44 & 73 \\
\hline 위생서비스(폭넓은 범위) & 60 & 22 & 46 \\
\hline 위생서비스(하수도) & 39 & 2 & 265 \\
\hline
\end{tabular}

출처: Joint Monitoring Program WHO/UNICEF(JMP/2006).17)

볼리비아는 현재 9 개 주에 327 개의 지방자치단체들이 포진되어 있고 14 개에 달하는 수자원 및 위 생시설 공급업체들이 존재한다. 특히 대도시 공급업체는 EPSA(Empresas Prestadores de Servicios de Agua Potable y Alcantarillado)가 이를 담당하고 있다. 농촌 지역에서는 훈타스(Juntas 혹은 물 17) http://www.wssinfo.org/data-estimates/introduction/ 참조. 
위원회)가 수자원 관리 및 시스템의 유지를 책임지고 있다. 수자원 관리 및 유지에 대한 볼리비아 정 부의 평균 투자는 1980 년대 2천만 달러 이하에서 머물다가 1990 년을 기점으로 대략 두 배인 4천만 달러로 상승했다. 그리고 1999년에는 연간투자 평균을 상회해 약 7천만 달러까지 상승했다. 하지만 2000년에는 이러한 투자가 약간 감소하다가 이후 점진적인 감소 경향을 보이고 있다. 중요 투자처를 살펴보면 1992-2000년 사이, 거의 58\%에 달하는 투자는 해외에서 지원되었다. 미주개발은행(IDB), 세계은행, 일본의 자이카(JICA) 그리고 독일의 개발은행이자 재건신용기구 KfW에 의해서 대부분 지 원되었다. 이외에 $17 \%$ 는 지방 정부들에 의해 그리고 $8 \%$ 는 사적 부문에서 나머지 $17 \%$ 는 주정부들에 서 재원을 마련한 것으로 보고되고 있다. ${ }^{18)}$

\section{2) 관개 및 배수 시설 분야}

볼리비아 정부는 향후 볼리비아 농업 생산량 확보와 농업 발전을 위해 관개 농업 분야 수자원 관 리가 가장 중요하다는 사실을 인지하고 있다. 국가 관개계획 등 정책적 혹은 제도적 장치를 마련하여 이 분야에 대한 투자를 강화하고 있다. 하지만 여전히 이 분야에 대한 시스템적 발전, 향후 투자, 기 술발전 등은 열악한 상태이다. 약 5,000 개에 달하는 관리 시스템을 가지고 있지만 지역적으로 남쪽 과 남서 지역, 예를 들어, 발에스(Valles) 및 알티플라노(Altiplano) 지역에 집중되어 있다. 하지만 이 러한 관개 시설들도 규제 조절 장치의 하나인 댐과 같은 시설은 거의 없고 시설이 정비되지 않은 상 태로 강우량에 의해 조절되는 복잡한 수로의 망으로 구성되어 있다. 이러한 열악함은 계절성 강우 조 절에 대해 상당한 취약성을 드러내고 있다. 여전히 전통적 방식과 좀 더 현대적으로 개선된 방식이 관개 방식으로 혼재하고 있다.

\section{3) 수력 발전}

1990년대 초반 볼리비아의 전력 부문은 민영화되었었다. 발전, 송전 그리고 배송 분야가 총망라되 었다. 볼리비아의 전력공급은 화력발전이 $60 \%$ 로 수위를 차지하고 있고 수력발전은 $40 \%$ 정도로 낮은 공급율을 보이고 있다. 이러한 혼합된 형태의 전력공급은 수력발전으로 많은 부분 전력을 공급하는 여타 다른 남미지역 이웃국가들(평균 $51 \%)$ 과 비교하면 낮은 수치이다. 여기에 농촌 지역에 대한 전 력 공급은 라틴아메리카 국가들 중에서도 최하위권에 머물러 있다. ${ }^{19)}$ 향후 볼리비아 정부에게는 최 대의 숙제로 남아있으며 공공 및 사적 부문에서 함께 해결해야하는 문제이다. 볼리비아의 전력부문 공급방식은 여타 다른 국가들과 마찬가지로 국가적 차원의 전력연결공급시스템(SIN)과 발전기를 갖 고 발전해서 직접 사용하는 방식인 오프 그리드(off-grid) 시스템(이른바, AISIADO 불리는) 방식으 로 이루어져 있다.

18) Vice Ministry of Public Investment and External Financing (2010 자료 분석)

19) $\mathrm{EIA}$ 통계자료 


\section{4) 지역 생태 보존과 농업 생산 증대}

볼리비아의 생태 시스템은 강유역의 특징과 상당히 밀접한 관련을 맺고 있다. 다소 폐쇄된 지역적 특성과 생태 특징을 보이는 지역은 볼리비아의 중앙 안데스 건조 지역으로 이 지역은 안데스 산맥 중 의 춥고 건조한 고원 지대로 구성되어 있다. 안데스 산맥 사이 계곡 지대는 산림 지역이며 이들 중에 서 동쪽 계곡은 열대 산림과 습한 대초원 사바나 지역이다. 다소 폐쇄된 공간으로서 생태 특징을 보 이는 지역은 초목과 강우량이 부족한 지역으로 $40 \%$ 의 인구가 살고 있고 대개 농업과 광산업에 종사 한다. 안데스 산맥 사이 계곡 지대는 가파른 경사지역으로 이 지역에는 반드시 관개시설과 토양 침식 을 막기 위한 계단식 테라스 시설이 필요하다. 이 계곡은 여타 지역들과 비교해 상대적으로 풍부한 곡물 생산이 가능해 볼리비아 경제 성장에 긍정적인 역할을 하고 있다. 동쪽의 열대 우림 지역에서의 수자원 관리 분야에서 필요한 사항은 배수 시설과 더불어 토양의 질 저하가 문제로 볼리비아 농업발 전을 위해 이 분야에 대한 관심이 시급하다. 이 지역에서 생산되는 농작물들은 대두, 목화, 해바라기 그리고 사탕수수 작물들이 주요 품목들이다.

\section{4. 볼리비아 정부의 수자원관리 전략과 국제개발협력}

위와 같은 다양한 분야에서 수자원 관리의 한계를 가진 볼리비아 정부는 향후 이 분야에 대한 경 제성, 공공성 그리고 생태환경 보호나 기후변화 대응 등에 많은 도전을 받고 있다. 이를 인식한 현 모랄레스 정부는 거시적 차원의 수자원 관리 전략을 국가사업으로 내세워 '모든 이들에게 물을(Agua para Todos)'이라는 슬로건 하에 이 분야에 대한 개선 정책을 마련하고 있다. 예를 들어, 지속가능하 고 모두가 참여하는 방식의 통합적 수자원 관리 국가 전략을 통해 강 유역 중심의 수자원 관리 개발 을 리드하고 있다. 국가 차원의 계획과 수자원 부문별 정보 프로그램을 구축하여 사막화 방지 프로그 램을 만들어 생태계를 보호한다는 전략을 운영 중이다. 이러한 전략의 이행에서 또한 가장 중요한 것 은 시민사회의 협력과 참여를 강화해 수자원 관리통합과 더불어 사회통합에도 일조한다는 계획이다.

위와 같은 전략적 마스터플랜을 통해 발생되는 경제적 영향을 살펴보면 기존의 수자원 이용에 대 한 지불 제도를 개선하여(특히 관개 부문) 수자원 시스템 개선에 활용한다는 입장을 보였다. 관개농 업 관련 부문 협회 및 이해 당사자들은 원가 보상이나 관개농업시스템의 확장 및 업그레이드 등의 분 야를 포함하지 않는 조건에서 수자원에 대한 세금 사항 규정 마련을 위해 책임을 지게 되었다. 농촌 지역에는 수자원 공급과 위생 관련 분야에 있어서 일인당 정부 보조금 정책이 활성화되었는데 물의 공급에서 70 달러, 위생 부문에서 60 달러 정도의 수자원 이용 보조금이 책정되었다. 게다가 내부 금 융 기금 마련을 위한 이자율 조정을 통해 간접적인 지원 정책이 마련되었으며 그리고 이러한 프로젝 트들은 비정부 기구들의 금융적 지원도 받아 들였다. 농촌 및 원주민 공동체들은 지금까지 수자원 이 
용에 대한 어떠한 비용도 지불하지 않았고 지난 시기에서도 이들은 볼리비아 내에서 가장 빈곤한 그 룹으로 존재하면서 수자원 이용과 관련된 법적 행위자로서도 배제 조항에 포함되어 있었다. 그럼에 도 불구하고 볼리비아 정부의 수자원 관리를 위한 실질적인 투자 사항들을 살펴보면 21 세기 초반에 는 상당히 감소하는 경향을 나타냈지만 최근 몇 년 사이에는 증가하는 경향을 보이고 있다(〈표 4〉참 조). 다음은 볼리비아 정부의 수자원 관리 투자(정부 예산과 실질 투자)에 대한 사항이다.

〈표 4〉볼리비아 정부의 수자원 관리 분야 투자: 1999-2007

(천 달러, \%)

\begin{tabular}{c|c|c|c|c|c}
\hline 연도 & 책정 예산 & 총예산에서 $\%$ & 실질 투자액 & 총예산에서 \% & 투자된 예산 \% \\
\hline 1999 & 4,979 & N/A & 2,134 & N/A & 42.9 \\
\hline 2000 & 3,666 & N/A & 5,840 & N/A & 159.3 \\
\hline 2001 & 6,803 & N/A & 8,335 & N/A & 122.5 \\
\hline 2002 & 6,803 & N/A & 8,335 & N/A & 146.9 \\
\hline 2003 & 119,527 & 2.4 & 85,249 & 2.2 & 71.3 \\
\hline 2004 & 74,849 & 2.0 & 95,542 & 2.2 & 127.6 \\
\hline 2005 & 61,283 & 1.3 & 140,102 & 2.7 & 228.8 \\
\hline 2006 & 113,531 & 2.0 & 146,102 & 2.7 & 228.6 \\
\hline 2007 & 162,245 & 1.8 & 242,132 & 3.0 & 149.2 \\
\hline
\end{tabular}

출처: 볼리비아 공공투자 및 대외 금융 차관부(Vice Ministry of Public Investment and External Financing 2009).

볼리비아 정부의 수자원 관리 투자의 증가와 더불어 국제개발협력 차원의 투자도 증가하기 시작했 다. 미주개발은행(IDB)의 경우 2008년 볼리비아의 수자원부와 함께 통합형 수자원 관리 전략 마련을 위해 30 만 달러의 프로젝트를 이행했다. 2007년 네덜란드와 스웨덴 개발협력사들은 이미 볼리비아 의 강 유역에 대한 수자원 관리 국가 계획에 협력을 강화해 코차밤바, 추키사카, 산타 크루즈 그리고 오루로 주(department)들을 중심으로 12 개의 강 유역 관리 사업에 6 백만 달러의 투자를 했다.

볼리비아의 관개 부문 관리를 위해 볼리비아 정부는 '안데스개발은행(Corporación Andina de Fomento: $\mathrm{CAF})^{\prime}$ 를 통해 1 천 6 백만 달러에 달하는 기금 마련을 했고 독일 정부로부터 1천 8백만 달러 그리고 미주개발은행(IDB)로부터 2 억 7 천만 달러의 투자 지원을 통해 몇몇의 관개 시설 개선 프로젝 트를 진행시켰다. ${ }^{20)}$ 세계은행 또한 볼리비아의 수자원 관리 프로젝트에 지원을 하고 나섰는데 이는

20) 일명 '카프(CAF)'로 불리는 '안데스개발은행' 은 일종의 안데스 지역 국가들이 개발협력 분야에 투자하는 다자 금융 기 구의 성격을 띤다. 베네수엘라의 카라카스에 본부를 두고 있으며 라 파즈, 브라질리아, 보고타, 키토 그리고 리마에 각 각 지부를 두고 안데스 국가들의 개발협력 사업에 대한 공적 사적 사업들에 투자를 해 오고 있다(규모는 2002년 기준 50억 달러). 
다음과 같은 개발 협력 사업들을 포함하는 개발협력 지원이다. 1) 수자원과 관련된 기후변화 적응 21 , 2) 재난 관리 및 긴급 복구, 3) 열대 안데스 지역의 급속한 융빙 현상에 대한 영향에 적응, 4) 도시 빈곤 계층을 위한 수자원 관련 인프라 구축, 5) 공동체 발전과 식량 안보에 대한 부문 등이 수자원 관리 지원 사업에 중요한 이슈들로 부각되었다. ${ }^{22)}$ 특히 기후변화로부터 복원력(climate resilience) 을 강화하는 방안을 주류화하는 프로그램(PPCR: Polot Program for Climate Resilience) 지원 사업 으로 5 억 달러 규모의 수자원 관련 국가발전 계획에 투자가 진행되고 있다. 이러한 국제개발협력을 통해 볼리비아는 수자원 관리를 통합적으로 진행할 수 있을 것으로 예상된다. 안데스 지역 개발 협력 기금들과 세계은행 차원의 지원은 향후 볼리비아 수자원 관리 부문에 많은 협력 사업들을 낳을 전망 이다.

위처럼 수자원 관리와 위생시설 개선에 대한 볼리비아 정부 인식의 변화 및 다양하고 포괄적 차원 의 투자와 제도적 개선 그리고 국제개발협력 기구 및 선진 공여국들의 국제개발협력 투자도 증가하 고 있다. 이와 더불어 좀 더 차별적 차원에서 볼리비아 같은 농업국가의 특수성을 감안해 수자원 관 리에서 동시에 반드시 고려해야 하는 부문이 농업 생산량 확대와 농업발전을 위한 효율적인 관개농 업시스템에 대한 국제개발협력도 중요하다.

\section{III. 볼리비아 농업발전과 관개농업의 영향}

상기했듯이 볼리비아는 농업과 광업의 비중이 높아 내부적으로는 물의 공급, 기후조건, 국제가격 변동 등과 같은 외부 충격에 취약한 경제구조를 가지고 있다. 특히 2006년 모랄레스 정권의 등장과 함께 에너지산업(천연가스)의 국유화, 취약계층에 대한 보조금 지원 등과 같은 무분별한 재정지출 증 가에 따라 재정상태도 그리 건전성을 띠지 못하고 있다. 〈표 5>에서 보듯이 볼리비아의 경제지표들 은 2007-2009년 사이 그리 낳은 형편은 아니다.

21) 2008년 세계은행은 기후변화와 개발협력 문제를 연계해 '개발과 기후변화에 대한 전략적 프레임워크(SFDCC: Strategic Framework on Development and Climate Change)'를 개발하였다. "세계은행의 대표적인 기금으로는 '기 후투자기금(CIF: Climate Investment Fund)'이 있다. 2008년 7월 설립된 CIF는 온실가스 배출 감축을 위한 청정기술 에 대한 투자 및 국가개발전략상의 저탄소 프로젝트에 대한 지원을 목적으로 한다. 총 공약액은 2009년 현재 63억 달 러에 달하며 실질적인 기여액은 57억 달러로 미국, 일본, 영국, 독일 등이 주요 공여국이다. CIF는 기존의 ODA와는 별도로 추가적으로 제공되는 재원으로 자금지원과 양허성 차관으로 구성된다" (정지원, 박수경 2010 참조).

22) 볼리비아는 방글라데시, 모잠비크, 캄보디아, 네팔 등과 같은 개도국 국가들과 함께 세계은행이 지원하는 '전략적기후 기금(SCF: Strategic Climate Fund) 중의 개도국의 국가개발정책 및 지속가능한 개발 전략에 기후변화로부터 복원력 (climate resilience)을 강화하는 방안을 주류화하는 프로그램(PPCR: Polot Program for Climate Resilience) 지원 국 가로 선별되었다. 
〈표 5〉볼리비아 주요 경제지표(백만 달러, 2007-2009)

\begin{tabular}{l|c|c|c}
\hline \multicolumn{1}{c|}{ 지표 } & 2007 & 2008 & 2009 \\
\hline $\mathrm{GDP}$ & 13,120 & 16,680 & 16,870 \\
\hline 수출액(백만 달러, FOB) & 4,458 & 6,527 & 4,918 \\
\hline 수입액(백만 달러, FOB) & 3,243 & 4,764 & 4,144 \\
\hline 수출 의존도 & $34 \%$ & $39 \%$ & $29 \%$ \\
\hline 외환보유액(백만 달러) & 4,498 & 6,871 & 7,311 \\
\hline
\end{tabular}

출처: IFS, EIU

이러한 이유로는 여전히 농업과 광업이 경제에 차지하는 비중이 크며 두 부문 중 재정수입의 $50 \%$ 가 천연자원에 의존하고 있기 때문이다. 에너지자원인 천연가스에 대한 자원국유화 정책 등은 정부 의 반시장적인 개입이 진행되고 있어 해외투자를 막고 있는 원인이 되기도 한다. 그럼에도 불구하고 오늘날 볼리비아는 수출지원을 위해 수출진흥청 같은 수출 촉진기구를 설립해 이러한 구조적 문제를 해결하고자 노력하고 있고 세계 금융 위기 극복 차원에서 2009년 경기부양책을 실시하기도 했다. 경 제 구조적 취약성 극복, 과도한 정부재정 지출에 따른 재정적자 해결, 열악한 국내산업 발전(인프라, 기술 등)은 볼리비아의 단기적인 문제가 아니라 중장기적으로 해결해 나아가야 할 문제들이다.

잘 알려진 대로 볼리비아는 남미지역 국가들 중에 최빈국에 해당한다. 남미지역에서 전통적인 농 업국인 파라과이와 더불어 국제개발원조가 필요한 국가 중에 하나이다. 국민 일인당 연간 평균소득 이 2006 년 기준으로 1,200 달러에 못 미치고 있고, 총인구에서 거의 $40 \%$ 정도가 극빈층으로 분류되 어 있을 정도이다. 게다가 볼리비아는 지니 계수(Gini Coefficient) 통계상 $0.6 \%$ 로 남미 지역에서도 가장 사회 불평등(social inequality)이 심한 국가 중에 하나이다. 소득의 양극화가 심한 이유이다. ${ }^{23)}$ 인구의 $10 \%$ 가 볼리비아 국가 총소득의 $40 \%$ 를 점유하고 있고 이와는 반대로 원주민공동체들과 농촌 인구들은 경제적으로 그리고 사회소외 계층으로 분류되어 고통을 받고 있다. 2008년 통계로 이러한 일인당 소득 수치는 지난 50년간 볼리비아 경제사회 구조 변화에서 바뀌지 않고 지속적인 현상으로 관찰되고 있다. 반면에 남미 이웃 국가들은 2008년 기준으로 브라질의 경우 소득 수준이 과거에 비 해 $350 \%$ 증가했고, 칠레는 $200 \%$ 그리고 아르헨티나는 $75 \%$ 정도 증가했다. ${ }^{24)}$ 빈곤 비율은 도시의 $54 \%$ 에 비해 농촌의 경우 여전히 83\%에 달하며 기초생활 불만족도에서도 도시와 농촌의 수준은 $39 \%$

23) '지니 계수(Gini coefficient)'는 소득 불균형의 정도를 나타내는 통계학적 지수로 이탈리아의 통계학자인 코라도 지니 (Corrado Gini)에 의해 1912년 처음 소개되었다. 지니 계수는 소득 분배의 불평등함 외에도 부의 편중이나 에너지 소 비에 있어서의 불평등함에도 응용된다. 계수의 범위는 0로부터 1로, 지니 계수는 0과 1 사이의 값으로 나타내며 0 에 가까울수록 소득이 균등하게 배분됨을 의미한다. 0 의 때에는 완전한 '평등'이며 모두 같은 소득을 얻고 있는 상태를 나타낸다.

24) 세계은행 볼리비아 국가정보 인용. 
대 $91 \%$ 로 대비를 보이고 있다. 세계은행의 보고에 의하면, 비록 2000년대 들어와 국가 전체 차원으 로 생활수준이 개선되고 있다고 하더라도 혜택은 여전히 도시 지역들에 집중되어 있다.

2000년-2004년 동안 볼리비아의 농업생산은 볼리비아 GDP에 $14 \%$ 정도의 기여를 했으며 고용부 문에서도 총인구의 $40 \%$ 가 이 분야에 종사하고 있다. 하지만 이러한 고용 수준은 농촌 지역으로 접근 하면 농촌 인구 중 거의 $80 \%$ 가 농업에 종사하는 것으로 통계가 잡힌다. 개별연도 통계 수치로 보면 2001년 농업 부문에서만 4 억 3,200 만 달러의 수출을 기록했으며 이는 볼리비아 국가 전체 수출의 $30 \%$ 에 해당한다. 볼리비아의 동쪽 지역은 농업 분야 수출에 막대한 영향을 주고 있는 대두, 해바라 기 그리고 사탕수수 등을 생산한다. 하지만 서쪽 지역에서는 지방 시장과 자급 농업 생산이 주를 이 루고 있다.

게다가 볼리비아 정치적 불안정으로 인한 정부의 빈번한 교체와 사회적 긴장 관계의 지속은 그동 안 볼리비아의 빈곤 감축의 개선에도 많은 한계를 드러냈다. 그럼에도 불구하고 2006년 처음으로 원주 민 출신 대통령으로 당선된 에보 모랄레스(Evo Morales) 정부는 새로운 '국가발전계획(Plan Nacional de Desarrollo: PND)'을 통해 이러한 근본적인 빈곤 문제를 해결하고자 노력하고 있다. 특히 관개농 업시스템의 개선과 증진 사업은 이러한 국가발전계획에서 핵심을 차지하고 있는 프로젝트들이다. 관 개농업 향상을 통해 농업 생산량을 증대시키고 생산품의 다변화를 유도하며 농촌 지역에서 일자리 창출은 물론 향후 볼리비아의 식량안보 확보에도 커다란 영향을 줄 수 있기 때문이다. 특히 볼리비아 의 수자원 부(Water Ministry)보고에 의하면 관개농업 증진은 향후 볼리비아 농촌 및 농업발전에 다 음과 같은 구체적인 분야들에서 긍정적인 효과를 가져 온다고 본다. ${ }^{25)}$ 예를 들어, 농업 생산량의 안 정적인 확보를 위한 기후변화 위협 감소, 생산량의 증대를 통한 수출 능력 증가와 이로 인한 농업 재 정 마련, 토지 이용의 강화, 소득 증대와 농촌에서 도시로의 국내 이주의 감소, 고부가가치 농업 상 품으로의 다변화, 생산 투자 증대 등의 장점들을 들 수 있다.

\section{1. 관개농업 시설 발전 현황}

볼리비아는 현재 대략적으로 총 경작 가능한 농업용 토지 210 만 헥타르(ha) 중에 $11 \%$ 에 달하는 23 만 헥타르에만 관개시설을 이용한 농업활동이 진행되고 있다. 5 천 개에 달하는 관개시스템을 확보하 고 있지만 대부분이 남부와 남서부 지방, 예를 들어 알티플라노(Altiplano) 유역에 집중되어 있다. 동시에 이러한 시스템들은 제대로 연결된 시스템이 아니라 복잡한 거미줄 망의 수로들로 연결되어 있으며 중간 중간에 댐 시설을 이용하기 보다는 일반 강우량의 흐름을 통로로서 통제하는 열악한 시

25) Viceministerio de Riego (Julio 2007). "Plan Nacional de Riego" (PDF). Ministerio del Agua. pp. 1-3. http://www.riegobolivia.org/documentos/PlanNacionaldeRiego/PlanNacionaldeRiego.pdf. 
스템으로 계절성 우기에 상당히 취약한 구조를 가지고 있다. 관개 시설들의 효율성 정도는 전통적인 시스템으로 18\%-30\% 정도로부터 좀 더 개선된 시스템 35\%-50\%로 다양하다. ${ }^{26)}$ 총 9개 주로 구성 된 볼리비아 지역 및 지방의 관계 시스템 발전 현황을 살펴보면 다음과 같다. 주마다 관개 시스템의 규모는 강우량과 농업용 토지 규모의 존재 및 정도에 따라 다르다. ${ }^{27)}$

〈표 6〉 볼리비아 지방 주들의 관개 시스템 발전 현황(헥타르 ha)

\begin{tabular}{l|r|r|r|r|c}
\hline \multicolumn{1}{c|}{ 지방 주 } & 10ha & 100ha & 500ha 미만 & 500ha 이상 & 총합 \\
\hline 추키사카 & 1,653 & 11,370 & 4,261 & 3,884 & 21,168 \\
\hline 코차밤바 & 1,938 & 22,225 & 27,403 & 35,968 & 81,925 \\
\hline 라 파즈 & 1,703 & 21,047 & 6,052 & 7,192 & 35,994 \\
\hline 오루로 & 940 & 3,638 & 440 & 9,021 & 14,039 \\
\hline 포토시 & 3,240 & 10,146 & 2,254 & 600 & 16,240 \\
\hline 산타 크루즈 & 269 & 5,456 & 8,434 & 1,080 & 15,239 \\
\hline 타리하 & 785 & 12,755 & 17,101 & 5,710 & 36,351 \\
\hline \multicolumn{1}{c}{ 총계 } & 10,528 & 86,638 & 65,944 & 63,454 & 226,564 \\
\hline
\end{tabular}

출처: 볼리비아 수자원 부 (Ministerio del Agua 2008)

관개시스템을 통해 인수(water withdrawals)되는 수자원 $94 \%$ 이고 이는 연간 20억 입방미터(cubic meters)에 해당한다. 볼리비아는 지형적 혹은 기후적으로 관개에 대해서 다음과 같은 세 지역으로 구분된다. 열대 및 아열대 기후 특징을 보이는 동쪽 지역과 건조, 반-건조 및 반-습지 건조 지역인 서쪽 지역 그리고 페루와 국경을 맞대고 있는 티티카카(Titicaca) 유역으로 나누어진다. 수계 지리학 적으로 살펴보면 역시 세 지역으로 구분되는데 먼저 72 만 4천 킬로미터에 달하는 아마존 지역은 볼 리비아 영토의 $66 \%$ 를 차지하며, 영토의 $21 \%$ 에 해당하는 리오 플라타(Rio Plata) 유역과 $13 \%$ 에 해당 하는 다소 고립적인 유역 등이 존재한다. 관개에 대한 중점적인 관리가 필요한 지역이기도 하다. 아 마존 유역은 수계의 크기 등을 고려해 보면 홍수 피해가 많은 지역이다. 세 지역으로 분류되는 볼리 비아의 관개 관련 해당 사항은 수자원이 풍부한 지역과 부족한 부족의 차이가 지역별로 너무 커 이에 대한 균형을 맞추는 관개농업시스템의 개발이 시급한 상황으로 분석된다. 물론 지역차를 극복하고 이러한 균형을 맞추기 위한 국제개발협력은 반드시 필요하다.

26) Comisión para la Gestión Integral del Agua en Bolivia, p. 1.

27) 볼리비아의 주는 북쪽으로부터 빤도(Pando), 베니(Beni), 수도인 라 파즈(La Paz), 오루로(Oruro), 포토시(Potosí), 타 리하(Tarija), 코차밤바(Cochabamba), 추키사카(Chuquisaca), 산타 크루즈(Santa Cruz)로 구성되어 있다. 


\section{2. 관개농업과 환경적 영향}

볼리비아에서 관개농업에 의한 영향은 농업용수의 범람으로 인한 토양 침식과 오염이다. 거의 $41 \%$ 에 달하는 토지들이 토양 침식으로 인해 생산성을 잃고 있다. 예를 들어, 볼리비아의 서쪽 지방 인 오루로, 포토시, 타리하 지방에서는 토양의 침식으로 인한 토지의 낮은 생산성을 가진 지역이 무 려 4만 5 천 평방킬로미터에 달할 정도이다. 고지대의 영세농 경작 지역인 '미니푼디오(minifundios)' 에서도 토양의 질 저하는 발생하고 있다. 북쪽 고지대 지역의 가족농 생산 단위는 5 헥타르 당 3 헥 타르 정도 수준으로 생산량의 감소를 가속화시키고 있다. 방목지의 증가와 여타 다른 농업 활동 또한 토양의 염류화와 토질의 쇠퇴를 증가시키고 있다. 28 ) 농업용수의 범람은 일반 가정에서 방출되는 생 활 오폐수와 산업 분야 및 광산 활동을 통해 나오는 유독물질 등의 투기와 더불어 수질 오염의 또 다 른 원인이 되고 있다. 오염 부하량에서 가장 큰 몫을 차지하는 것은 농업, 어업 활동 그리고 도시 지 역에서 발생하는 쓰레기 오폐수 등에서 나오는 유독 물질들의 확산에서 기인한다. 하지만 이런 원인 들을 제거(양이나 독성 등)하기 위한 규제 조치들은 없다.

\section{3. 관개농업 분야 정책 및 제도 발전}

스페인의 식민 지배자들의 중앙 안데스 지역에 도착한 16 세기 이후 기존에 이 지역에 거주하던 수 많은 원주민 공동체들은 저지대의 연안 지역과 계곡에 존재하던 비옥한 토지들을 빼앗기고 인간 거 주가 힘든 고지대로 밀려 나야 했다. 고지대에서는 야마(llama)나 알파카(Alpaca) 같은 동물들을 사 육하기 위한 방목 지대가 증가했지만 이러한 동물들은 낮은 생산성과 높은 기후적 위협 등으로 농업 에 이용되지 않았다. 고지대는 현재 볼리비아 농업 생산에서 자급농 특징만이 남아 있다.

전통적으로 볼리비아 정부들은 광산 부문에 의존해 국가 재정 수익과 외화를 벌어 들였다. 직접적 으로 농업 부문은 국부의 원천이 되지 못했다. ${ }^{29)}$ 하지만 1985년 파즈 에스텐소로(Paz Estenssoro) 정부가 추진한 경제개혁 조치로부터 이러한 흐름은 변화를 가져왔다. 자유 시장 경제 논리에 따라 농 업 부문에 대한 해외 투자를 유인하는 경제 정책들을 입안하면서 사적투자를 강화시키고자 하는 움 직임을 보였다. 하지만 농업발전을 위한 초기의 이러한 시도는 일종의 공공재 차원에서 필요했던 토 지소유권, 농업 리서치 및 진흥계획, 관개 인프라 등에 대한 정확한 그리고 건설적인 국가 개입 계획 이 없어 성과를 내지 못했다. 결과적으로 농업 부문 발전은 위한 인적/물적 자본의 부족으로 한계를 드러냈으며 농촌 공동체들은 특히 관개 기술의 부족으로 인하여 생산성 향상에 대한 기회를 박탈당 해야 했다. 1999년대에 들어서 관개시설을 통한 농업 생산 가능 토지가 128,240 헥타르로 증가했다.

28) Sanchez-Triana, Ernesto, et al.(2006: 421-437) 참조.

29) World Bank (1992: 1-3). 
하지만 이러한 증가에도 불구하고 또 다른 문제는 이러한 관개 인프라가 코차밤바 지역과 라 파즈 지 역에 $50 \%$ 이상이 집중되어 있다는 사실이다. ${ }^{30)}$

제도적 발전 측면에서 살펴보면 1990년대 동안 볼리비아의 수자원 관리 특징은 수많은 행위자들이 포함된 부문적 접근 방식으로 이루어져 있었으며 관리에 대한 책임 소재도 여러 기구들에 의해 다층 적으로 진행되었다. 농촌 및 원주민부, 국가수자원 관리기구, 수자원 위원회 간 혹은 관개 및 배수 국가사무국, 농촌발전 국가사무국 등이 국가 차원의 수자원 관리나 관개에 대해서 업무를 중첩적으 로 맡고 있었다. 하지만 볼리비아 정부는 1998년 이런 복잡한 업무 분담을 해결하기 위해 수자원 이 용자 권리를 허가하는 한편 전담 관할부서의 설치를 해결책으로 내 놓았다. 1999년 라 파즈 지역과 코차밤바 지역에서 수자원과 위생에 관한 두 중요한 부문에 대한 사적 기업들의 참여 가 허가되었다. 결과적으로 수자원 이용료가 증가했고 비용측면에서 수자원에 대한 일반 소비자들의 접근은 점점 어 려워 졌다. 이러한 원인들이 2000년 볼리비아에서 ‘물 전쟁' 이라 불리는 엄청난 규모의 사회저항 운 동이 발생했고 이 사건 이후 볼리비아의 수자원 소비자 협회, 정부 및 지방정부들, 비정부기구들, 국 제리서치 기관들이 참여해 수자원 이용에 대한 공공정책을 재조명하면서 재정의 하기 시작했다(Box 1 참조).

이러한 과정은 소비자들의 물이용권 프로젝트(Proyecto Derechos de Agua - PDA)로 이어졌다. 관개농업 관련 기구들은 $\mathrm{PDA}$ 과정 속에서 새로운 희망을 얻었고 이들 기구들과 함께 기술적으로 볼 리비아의 전통적인 이행과 과학적 지식이 결합된 형태의 국가차원의 관개 전략을 모색하기 시작했 다. 이러한 참여 과정에서 제도적으로 발전한 것이 여타 다른 법안들과 함께 태어난 2004년 관개 법 (Irrigation Law) No.2878 이었다. ${ }^{31)}$ 2006년 정권을 잡은 모랄레스(Morales) 정부는 이를 더욱 강 화하여 제도적 개혁을 이루었는데 볼리비아의 새로운 수자원 이용 및 관개농업을 담당할 환경 및 수 자원 부를 새롭게 구성했으며 이는 중앙정부 통제방식보다는 이 분야에 대한 지방자치도 인정하여 (지방자치법 No. 1654 근거) 지방정부들에도 담당 부서 및 수자원 이용자 협회 등을 두고 종합적으 로 관리할 수 있는 시스템 개혁을 이루었다. 하지만 국가 차원의 관개 계획은 여전히 중앙정부 및 지 방 정부 차원에서 서로 다른 기관들이 포함되면서 상당히 중첩된 형태의 관리 및 책임이 맡겨져 여전 히 문제로 지적되고 있기도 하다.

2004년에 태어난 관개 법(Irrigation Law) No. 2878은 탈중앙화 방식의 다시 말해서 지방정부들 의 권한 강화를 통해 관개로 이용되는 수자원 관리와 등록을 통한 수자원 이용자들의 권리를 보장하 는 내용을 담은 제도적 노력을 함축한 법안이다. ${ }^{32)}$ 관개 법(Irrigation Law) No. 2878은 또한 관개

30) FAO 볼리비아 국가 개황 참조 및 인용.

31) http://www.aguasustentable.org/documentos/derechos/folleto.pdf. 
인프라 시설 구축과 관리를 지방의 농촌 공동체에 이양하는가하면 관개시스템의 투자 증진을 위한 참여 메커니즘을 구축하는 데에도 많은 역할을 했다. 새로운 관개 법은 수자원 이용 권리에 대한 이 양을 금지하는가 하면 새로운 수자원 시장을 활성화시키고 개인적인 수자원 이용자들의 권리보다는 집단적인 소비자 권리를 강화한 법안으로서 특징을 갖는다. 물론 이러한 권리의 취득은 사전 등록이 라는 제도적 절차를 밞아야 보장이 된다. 등록은 원주민, 일반 가정들, 공동체 차원에서 가능하며 국 내의 혹은 전통적인 농업 부문에도 허용이 된다. 물론 여타 농업 및 농 - 산림업에 종사하는 다양한 농민 기구들에 최대 40 년 동안 수자원 이용에 관한 등록이 허용된다. 이전에는 농업부에서 이를 담 당했지만 관개와 관련된 이러한 모든 등록과 관리의 문제는 수자원부에서 관할한다. 이러한 행정적 업무를 위해 수자원부는 국가 관개 서비스(Servicio Nacional de Riego - SENARI)와 지방 관개 서 비스(Servicio Departamental de Riego - SEDERI)를 제공하고 있다. 행정조직 구성을 살펴보면 다 음과 같다.

먼저, 환경 및 수자원 부(Environment and Water Resources Ministry)는 2009년 설립되었으며 다음과 같은 업무에 책임을 담당하고 있다. SENARI와 공조 하에 볼리비아 관개 시스템에 대한 계획 수립과 정책 마련 및 이의 이행, 모니터링 그리고 기금마련; 국내 및 국제 기금의 관리를 통해 관개 시스템 발전에 노력; 기술적 지원 증진과 관개 발전을 위한 리서치 및 개발; 관개 법 2878에 의거한 강 유역별, 지방 및 시와 주 단위별로 관개에 대한 지방자치 독려; 농촌발전, 농업발전 그리고 환경 보호에 대한 동일한 책임성 공유 등이 주 업무이다. 관개 담당 차관부는 관개 시스템을 이용한 지속 가능 수자원 이용을 보장하고 점진적인 관개 시스템 향상과 구축을 위한 수자원 이용 권리와 허가를 담당하며, 국가 차원과 지방 정부 차원의 투자를 활성화하고 기술과 금융적 지원을 통한 제도적 능력 을 강화하기 위해 설립되었다. 발전계획 부는 수자원 부, 농촌발전 부 및 농업과 환경부와 함께 강 유역 수준에서 수자원 관리에 대한 감독과 계획을 담당하며 관개 시설 활동에 환경 기준의 이행과 디 자인하고 수질의 모니터링과 수질 오염의 완화하는 업무를 담당한다. 수자원 부 산하의 SENARI의 경우는 수자원 정책의 계획과 이행에 총괄적인 책임을 진다. 수자원 이용 권리를 허가함은 물론 수자 원 이용에 관한 갈등을 해결하고 다른 수자원 이해당사자들과의 협력을 도모하며 SEDERI를 감독한 다. 주 단위로 존재하는 SEDERI는 주단위로 관개 전략을 계획하고 주의 관개 서비스 담당 부서를 총 괄하며 관개 부문 등록을 담당한다. ${ }^{33)}$

32) 1906 년 제정된 이전의 법은 용도폐기 되었음.

33) 볼리비아의 주들 중에서 현재 7개의 주에 SEDERI 가 존재한다. 수도인 라 파즈(La Paz)를 포함해 오루로(Oruro), 포 토시(Potosi), 타리하(Tarija), 코차밤바(Cochabamba), 추키사카(Chuquisaca), 산타 크루즈(Santa Cruz)에 있다. "티 agua y el derecho de acceso" (PDF). Agua Sustentable. pp. 1-3에서 참조. 
이외에도 볼리비아에는 관개 및 수자원 이용과 관련해 지방과 지역 그리고 강 유역과 주 단위로 다수 존재하며 이들은 공식적으로 협회, 협동조합, 위원회, 공동체 방식으로 협력하고 있다. 새로운 수자원 법을 통해서 볼리비아 정부는 수자원 이용자 권리를 등록하는 과정에서 비공식적인 단체들의 참여를 증진시키고 있다. 이러한 참여는 국가차원의 기구를 통해서도 가능하지만 지방 및 주 단위로 존 재하는 기구들 예를 들어, 관개 부문 주 연합(UDR; Unidades Departamentales de Riego)이나 주 단 위 관개 협회(ADR; Asociaciones Departamentales de Regantes) 등이 관여되어 있다(Viceministerio de Riego 2007). 모랄레스 정부는 위와 같은 법과 기구 등 제도적 개혁을 통해 관개시스템의 변화를 추구하는 한편, 정책 결정 과정에서 많은 행위자들의 참여를 요구하고 있으며 이들의 의견을 모아 강 유역 수준에서 보다 통합적 차원의 수자원 관리와 공공 투자를 강화한다는 목표를 세유고 있다. 이러 한 목적 달성을 위해 2007년 볼리비아 정부는 2030년까지 국가 관개 계획인 새로운 '프로나르 (PRONAR)' 프로그램 이행에 들어갔다. ${ }^{34)}$ 1996년-2005년까지 이행되던 이전의 PRONAR 프로그램 과는 달리 현재 이행 중인 프로그램은 농·산림 생산, 수자원 관리, 관리 기구 및 제도적 능력, 관개 및 배수 인프라 시설 투자 증대, 통합적 기술 지원, 등을 통해서 관개 인프라를 27만 5 천 헥타르(ha) 로 증진시켜 20만 명에 달하는 농민들에게 혜택을 주고자 하는 계획으로 2030 년까지 투자될 재원이 12 억 달러에 달한다. ${ }^{35}$

농촌공동체(농민)는 볼리비아 관개 인프라의 이행과 유지비용을 지불하고 있는 중요 행위자이다. 볼리비아 수자원 부의 보고에 의하면 수자원 이용자들이 볼리비아 관개시스템의 관리 및 유지비용을 거의 $45 \%$ 정도 보전하고 있다. 볼리비아 관개시설 총 규모의 근 $10 \%$ 를 담당하는 산타 크루즈 주의 과달루뻬(Guadalupe)와 팜빠 레돈다(Pampa Redonda), 코차밤바 주의 치아라(Chiara) 관개시스템 등의 경우는 이용과 함께 비용을 지불해야 한다. 예를 들어, 코차밤바에서 수자원 이용자들은 신청수 수료 4 달러와 등록비 10 달러 정도를 지불해야 하며 사무개선 활동비 혹은 관리비 명목으로 하루당 3 달러 정도의 이용료를 지불하고 있다.

이러한 수자원 이용료와 더불어 관개시설 투자에도 많은 금융적 지원이 이루어지고 있다. 2001년 관개를 포함하는 농촌발전기금으로 투자된 금액이 1 억 3천 3 백만 달러에 달했으며, 2002년에는 1 억 6 천 8백만 달러로 증가하기도 했다. 이러한 막대한 양의 투자는 대부분 지방정부들에 의해 이행이 되었지만 시스템 개선 이후에 이러한 부문에 대한 소유권의 개념은 명확하게 정의되지 않았었다. 1996년-2005년 사이 PRONAR 차원에서 투자된 프로젝트만 볼리비아 총 9개 주 중에 7개 주에 158

34) http://www.riegobolivia.org/documentos/PlanNacionaldeRiego/PlanNacionaldeRiego.pdf.

35) Smits, Step, et al., p. 1. http://wnw.iclei-europe.org. 
개에 달하며 투자비용만 해도 2천만 달러로 대부분이 국제개발은행(IDB)과 관개 부문 관련 협회 및 지방정부들의 투자에 의존해서 이루어졌다.

〈표 7〉볼리비아 주별 관개 부문 투자와 투자처(달러, 2005)

\begin{tabular}{l|r|r|r|r|r|r|r}
\hline 주 명 & 프로젝트 & 지방자치 & 농민 & $\begin{array}{r}\text { 관개된 } \\
\text { 헥타르 }\end{array}$ & $\begin{array}{r}\text { 입찰/프로 } \\
\text { 나르 투자 }\end{array}$ & $\begin{array}{c}\text { 지방정부 } \\
\text { 투자 }\end{array}$ & 총합 \\
\hline 코차밤바 & 20 & 16 & 3,210 & 1,983 & 236만 5천 & 62만 & 300만 \\
\hline 추키사카 & 34 & 16 & 1,612 & 2,367 & 271만 9천 & 78만 & 350만 \\
\hline 라 파즈 & 32 & 19 & 3,077 & 4,584 & 320만 1천 & 98만 & 418만 \\
\hline 오루로 & 26 & 7 & 1,326 & 1,885 & 174만 & 55만 & 229만 \\
\hline 포토시 & 12 & 4 & 1300 & 706 & 104만 & 36만 & 140만 \\
\hline 산타쿠르즈 & 9 & 8 & 554 & 699 & 91만 & 27만 & 118만 \\
\hline 타리하 & 25 & 13 & 1,477 & 2,170 & 272만 & 90만 & 362만 \\
\hline 총합 & 158 & 84 & 12,556 & 14,396 & 1,471만 & 446만 & 1,917만 \\
\hline
\end{tabular}

출처: Ministerio de Asuntos Campesinos y Agropecuarios (2005)

\section{5. 기후변화에 의한 관개농업에의 영향}

관개 부문에 대한 기후변화의 영향은 아직 자세히 보고되고 있지는 않다. 하지만 '엘 니뇨(El Nino)' 현상으로 발생하는 볼리비아의 홍수, 가뭄, 서리 및 우박 등으로 인한 농작물 피해 현상은 볼 리비아에서 일상적인 일이 되었다. ${ }^{36)}$ 자연재해로 인한 농업 부문의 피해는 크다. 농촌 공동체의 삶 에 직접적인 영향을 주고 있으며 농촌 사회 복지에도 많은 영향력을 주고 있기 때문이다. 농작물 피 해뿐만 아니라, 사회 인프라인 도로의 유실, 에너지 및 관개 인프라에도 막대한 피해를 주고 있다. 이러한 피해로 인하여 제대로 농촌에서 농작물이 공급되지 않으면서 시장의 공급과 수요 곡선의 균 형을 깨트려 인플레이션 문제를 일으키고 있기도 하다. 물론 이러한 인플레이션 현상의 만성화는 빈 곤의 문제와 바로 연결이 된다.

우기에 발생하는 빈번한 홍수와 산사태는 많은 분야 사회 인프라에 치명적인 영향을 주어 왔다. 예를 들어, 1997-1998년 사이 수도인 라 파즈 지역의 코타우마(Cotahuma), 모코토르(Mokotor) 그 리고 쿠니(Kunii) 공동체에서 발생한 산사태는 볼리비아 정부의 보고에 의하면 24 명의 희생과 거의

36) 해양학 및 기후학에서 논하는 '엘니뇨' 현상은 남아메리카 서해안을 따라 흐르는 페루 해류 속에 몇 년에 한 번 이상 난류가 흘러드는 현상이다. 에콰도르에서 칠레에 이르는 지역의 농업과 어업에 피해를 주고, 태평양의 적도 지방과 때 로는 아시아 및 북아메리카에도 광범위한 기상 이상 현상을 일으킨다. 
300 채에 달하는 가옥이 붕괴되었다. 2002년 역사적으로 유례가 없을 정도의 해일 폭풍으로 인하여 70 명의 사상자와 7 천만 달러 정도의 경제적 피해라는 결과를 낳았다. 농촌 지역에서 발생하는 가뭄 의 피해는 농작물 생산에 불리한 조건을 만들면서 농촌에서 도시로 떠나는 국내 이주 현상을 가속화 시켰다. 게다가 안데스 산맥의 고지대 온도가 상승하면서 발생하는 빙하의 녹는 현상은 단기간에 계 절에 따른 지표 유거수(流去水)가 대량으로 흘러내림으로 인해 자연 및 환경 피해를 유발할 수 있 다. ${ }^{37)}$ 농업에도 심각한 단기성 강수량 의존 구조를 만들어 중단기적인 농업 생산에 막대한 피해를 줄 수 있다. 실질적으로 수도인 라 파즈 북동쪽 20 킬로미터 떨어진 지점에 위치한 차칼타야 (Chacaltaya) 빙하의 경우는 1982년을 시작으로 녹기 시작하여 2013년 이르면 완전히 녹아서 사라질 운명에 처해 있다.

\section{6. 관개농업 시스템 구축과 국제개발협력}

세계은행의 경우, 2009 년 개발협력 차원에서 볼리비아 관개농업 분야 제도 개선을 위한 국가, 지 방정부 및 시민사회가 공동으로 참여하는 농촌투자 프로젝트에 약 7천 8백만 달러의 투자를 진행했 다. 물론 좀 더 포괄적인 투자 항목을 보면 이외에도 산림과 어업 분야가 포함되어 있다. 하지만 중 요 투자 포인트는 관개농업에 관련된 투자가 중심에 있다. 이와 더불어 세계은행은 볼리비아 또 다른 국가 계획인 '지속가능한 재건과 복원(PRRES)' 계획에 부응하여 1 천 2 백만 달러의 투자를 지원했 다. 이러한 계획은 볼리비아의 긴급 복원 및 자연재해 관리 프로젝트의 일환으로 위험관리 및 국가시 스템 강화를 위해 필요성이 부각되었다. 물론 이러한 투자의 주요 대상 지역은 과거에 엘니뇨에 의해 직접적인 피해를 받은 지역들을 대상으로 하고 있다. ${ }^{38)}$

미주개발은행의 경우는 볼리비아 관개 프로젝트 디자인과 평가 부문에 투자를 진행하고 있고 독일 의 GTZ도 기술 및 금융 지원을 통해 볼리비아 관개농업 분야 시스템 구축에 협조하고 있다. ${ }^{39)}$ 기존 볼리비아의 수자원 관리 계획이었던 PRONAR가 2005년 완료됨에 따라 볼리비아 정부는 연속해서 이 계획을 지속해 나갈 국제협력이 요원한 상태이다. 따라서 현재 국제기구 및 개별 국가들의 관개농 업시스템 구축에 대한 국제원조는 볼리비아 정부의 이 프로젝트에 대한 지속성을 담보해 주고 있다. 동시에 기존의 PRONAR 계획은 다음과 같은 몇몇 중요한 교훈을 남겼다. 예를 들어, PRONAR의 경 우 관개 필요 수량과 수자원 유용성 부분에 중심을 두고 구상되었다. 하지만 관개 인프라 구축을 위 해서는 사회적, 수문학적 그리고 지형학적 데이터들도 동시에 고려되어야 한다. 이러한 고려는 관개

37) Francou, Bernard, et al.(2000: 1-2).

38) http://www-wds.worldbank.org/external/default/WDSContentServer/WDSP/IB (2008년 03.11).

39) "BO-T1039 : Evaluation and Design of Irrigation Project"(http://www.iadb.org/projects) and "GTZ" (http://www.gtz.de/en/)에서 인용 및 참조). 
인프라 구축 과정에서 발생할 수 있는 기술적 문제들을 해결할 수 있기 때문이다. 이와 더불어 이러 한 인프라 구축 과정에는 이를 관리하고 모니터링 할 수 있는 강한 지방 기구의 존재가 중요하다. 물 론 공공투자를 통한 공공사업의 일환으로 진행되는 인프라 구축이기 때문에 제도적으로 그리고 정책 적으로도 충분히 뒷받침되어야 한다. 사적부문 투자를 통한 인프라 구축은 종종 그 책임성과 연관이 있기도 하다. 법적 혹은 제도적 장치는 시스템의 사후 관리에도 많은 영향을 미칠 수 있기 때문이다.

\section{IV. 나오며}

21 세기 한국의 라틴아메리카 지역(특히 볼리비아) 국제개발협력(ODA)사업 진출 분야 중에 현재 잠재성이 뛰어난 하나는 수자원 관리 및 관개농업 시스템 구축이다. 이 분야에 대한 개발 절박성은 상당하다. 농업국가의 특징을 갖고 있는 개도국들에 대한 수자원 관리 분야 접근은 시대적 요청이기 도 하다. 이러한 요청은 오늘날 국제개발협력 기구들이나 개별 선진국들이 진출하고 있는 구체적인 협력 사업들 중의 하나이지만 수원국들의 금융투자 및 기술협력 사업 요청이기도 하다. 특히 농업 생 산성 향상을 위한 새로운 농업발전 시스템 구축의 일환과도 맥을 같이 한다. 라틴아메리카의 경우 2011년 오늘날 개발원조 핵심 대상 국가들로 떠 오른 빈곤 국가들(볼리비아, 파라과이, 페루, 과테말 라 등)의 경우에는 이 분야에 대한 개발 및 국제협력 요청이 증가하고 있는 추세이다. 이러한 경향들 을 고려해 본 논문은 볼리비아의 지속적인 개발협력 의제인 혹은 볼리비아의 향후 경제발전은 물론 농업발전과 환경보호 및 기후변화 대응, 수질 및 위생서비스 강화, 지속가능한 자원개발 및 보존 등 의 측면에서 가장 문제로 직면하고 있는 수자원 관리 및 관개농업시스템 구축 분야를 선정해 그 현황 과 이 분야에 대한 정부 인식의 변화와 개발 절박성 그리고 한계점들과 구체적인 협력 가능성을 집중 적으로 점검해 보았다. 특히 현재 이 분야에서 진행 중에 있는 많은 국제개발협력 사업과 더불어 관 련 법적/제도적 발전과 문제점들을 살펴보았다.

한국이 이제 국제개발협력과 원조사업의 혁신을 통해서 그 효과와 라틴아메리카 빈곤퇴치에 기여 도를 높이는 방법은 한국이 가진 비교우위를 잘 살려 원조의 본래 목적인 발전과 빈곤감축에 기여해 야 한다. 이와 동시에 국제개발협력 사업은 이전의 단순 물자지원에서 방식에서 벗어나 수자원 관리 및 관개농업 시스템과 인프라 구축과 같은 SOC 사업에 적극적으로 참여해야 한다. 수자원 관리에서 (특히 통합관리 분야: 최동진 2010) 상대적으로 강한 비교우위와 발전 경험을 가진 한국은 볼리비아 의 수자원 관리 및 위생시설 구축 사업, 그리고 관개농업시스템 구축에 국제협력의 네트워크를 구축 해야 한다. 수자원 관리, 위생시설 및 상하수도 건설, 오폐수 처리 등 수자원 분야 SOC에 참여해 볼 리비아 같은 개도국이 직면해 있는 다양한 환경오염, 수인성 질병 예방은 물론 관개농업시스템 구축 협력을 통해 개도국의 농업 및 산업 발전에 기반이 되는 농업용수 공급(볼리비아의 경우 농업용으로 
$82 \%)$ 효율화 등의 분야에 적극적으로 참여해야 한다. 이러한 분야 진출은 향후 장기적인 측면에서 보 면 볼리비아 경제성장과 빈곤퇴치에 커다란 기여를 할 수 있다. 좀 더 구체적인 개발협력의 필요성과 국제협력 진출 이유를 고찰해 보면 다음과 같다.

첫째, 상기했듯이 볼리비아 수자원관리 및 관개농업시스템 구축을 통한 볼리비아 정부의 농업발전 과 빈곤감축을 들 수 있다. 이는 현재 UN을 비롯한 다양한 국제기구(IMF, IDB, 세계은행) 및 개별 선진 공여국들이 볼리비아의 경제발전과 빈곤감축 프로그램들을 통해 볼리비아의 수자원 관리 분야 에 적극적으로 참여 있으며, 제도적으로도 개혁추진 과정에 구체적으로 참여하고 있는 사례들에서 확인된다. 특히 세계은행과 미주개발은행의 경우는 신규융자와 채무삭감의 조건으로 수자원 관리(특 히, 수도사업, 위생시설사업, 관개농업)에 적극적인 관심을 나타내고 있다. 둘째, 무분별한 수자원 관리 및 개발에 의한 수자원 보호를 위해 '지속가능한 발전' 차원에서 수자원 관리 및 운영 방향이 바 뀌고 있다. 이는 기본적으로 국제협력 및 공조를 통해 수자원 관리 인프라 개발이 개도국의 지속적인 성장과 빈곤 해결에 있어 근본적으로 중요하지만 이러한 문제 해결에 있어 기존의 정부나 몇몇 기업, 혹은 정부 엘리트가 결정하는 방식이 아닌 실질적인 수자원 이용자들의 참여를 통해 의사결정이 되 고 정책이 반영된다면 이 또한 MDGs 차원의 민주주의 발전에 도움이 되기 때문이다. 볼리비아는 이 러한 과정을 통과하고 있다.

셋째, 물과 위생분야에 있어 볼리비아 정부의 관리능력을 배가 시킬 수 있다. 특히, 거액의 초기투 자를 필요로 하는 수도사업의 경우 볼리비아 정부가 충분한 자금을 확보하기가 곤란하다는 점에서 자금 확보를 위해 차관도입과 채권발행 등 채무증가로 이어지고 결과적으로는 서비스 질이 악화될 수 있는 데 이에 대한 국제개발 차원의 투자 협력은 이러한 악순환을 해소시켜 줄 수 있을 것이다. 넷째, 볼리비아 수자원은 현재 볼리비아 정부가 인식하고 있는 공공재로서의 기능회복을 도와 줄 수 있고 특히 빈곤 계층들에게 효율적인 공급을 서비스 할 수 있다. 수자원 관리 및 개발은 지속적 성장 과 빈곤해소를 위해 중요한 분야임에도 불구하고 볼리비아의 경우 보편적 서비스에서 소외되는 계층 이 확대되어 왔다. 공공재의 기능을 회복시키기 위해서는 풍부한 경험과 능력을 보유한 한국을 포함 하여 다양한 해외 개발협력체들이 참여함으로써 서비스의 질과 공공성을 확보할 수 있다는 것이다. 이러한 논리는 특히 이 분야에 특화된 기술을 확보한 한국 민간 기업들의 참여를 유도할 수 있다. 특 히 기업의 이익과 더불어 기업사회적책임(CSR)이 강조되고 있는 요즈음, 볼리비아 혹은 여타 라틴아 메리카 개도국의 수자원인프라 협력은 좋은 선례를 남길 수 있다. 인프라 시설 개선의 효과를 가져 올 수 있으며, 빈곤층의 선택지가 확대됨으로써 결과적으로는 정부의 재정 경감과 함께 기업의 이익 도 추구할 수 있다는 이점이 있다.

다섯째, 수자원 관리를 통한 볼리비아의 기후변화에 대한 대응과 적응 전략에 일조할 수 있을 것 
이다. 효율적인 수자원 관리는 결국 급속한 기후변화를 완화하고 지속가능한 발전의 중심이 되기 때 문이다. 지구온난화 과정에서 발생하는 엘 니뇨/라 리냐, 안데스산맥의 융빙현상 등은 볼리비아 개 별 국가가 단독으로 해결하기에는 너무나 부담이 크다. 국제사회의 공동체적 노력이 필요한 부분이 다. 여섯째, 특히 관개농업 분야에서 수자원 관리는 농업 국가의 특징을 보이는 볼리비아 같은 개도 국에게 장기적 차원의 농업생산성 증가는 물론 농촌 공동체들에게 일자리 창출과 이로 인한 농가 소 득의 증대에 영향을 미쳐 농촌 공동체들의 빈곤문제를 실질적으로 해소해 줄 수 있다. 마지막으로 효 율적인 수자원 관리는 수자원과 관련된 중앙정부와 지방정부 사이의 다양한 행정적 갈등(예를 들어, 조세 및 관리 유지의 책임성) 그리고 수자원 공급자와 수급자 사이에 발생할 수 있는 다양한 사회적 갈등을 해소해 사회통합을 유도할 수도 있는 분야이다. 볼리비아에서 수자원 관리 위기의 하나로 발 생한 '물 전쟁'은 원주민 공동체들과 중앙정부, 지방정부 그리고 민간기업 간의 갈등이 언제든지 재 현될 수 있는 소지를 남겼다.

현재 볼리비아 정부는 전통적인 농업 국가로서 정체성을 인식하여 자국의 농업 발전을 위한 일환 으로 이러한 열악한 상태의 수자원 관리 및 관개농업 시스템의 전환을 통해 농촌 지역의 삶의 질을 개선시키고 농촌 공동체들의 향후 발전을 물론 장기적인 차원의 개발 전략을 모색하고 있다. 특히 볼 리비아 농업생산 구조를 개선하고 및 이를 통한 경제발전 및 성장이라는 시너지 효과 창출을 위해 노 력을 하고 있다. 이러한 인식의 전환은 기존의 수자원 공급 방식의 정부 책임을 인정하고 대대적인 제도적 개혁을 통해 특히, 관개농업 부문에서 효율적인 수자원 관리를 약속하고 있다. 예를 들어, 기 존에는 몇몇 국가 정부 엘리트들에 의해 혹은 기업을 중심으로 관리되어 왔던 구조를 개선하여 수자 원 정책에 대한 지역의 농촌공동체 및 원주민 공동체들까지 확대해 의사결정에 참여시키고 있다. 의 사결정 방식이 투명해 지고 있다. 수자원 및 관개 시스템 관리에서 전통적인 방식과 새로운 기술 통 합을 모색하고 있으며 수자원 이용에 관한 권리 등록과 허용, 관개 인프라의 효율성 증진, 수질의 강 화, 이 분야 시스템 개선을 위한 정부의 필요 투자 확대 및 재정의 지속적이고 안정적인 투자 등을 통해 수자원 정책의 통합관리 방식으로의 변화를 보이고 있다. 하지만 이러한 내부적 제도 개선, 투 자 증대, 혹은 인식의 변화와 더불어 이 분야에 대해 실질적인 양적/질적인 발전을 도모하기 위해서 는 선진 공여국들의 국제협력 공조가 반드시 함께 해야 될 것이다. 특히 한국의 경우는 이 분야에 대 한 선도적인 기술이 있고 농업발전과 연계한 수자원 관리의 풍부한 경험과 노하우가 있다. 이 분야에 대한 발전 경험과 실질적인 성과를 내고 있는 한국 정부의 역할이 기대된다. 


\section{참고문헌}

\section{1. 책, 논문, 웹사이트 DATA}

김영진, “우리나라 수자원 인프라 개발경험과 ODA", 『한국의 개발협력(Journal of Korea's Development Cooperation) 1월호』(대외경제협력기금(EDCF), 2011) pp. 17-29.

이성형, 『신자유주의의 빛과 그림자: 라틴아메리카의 정치와 경제』(한길사, 2001)

정지원, 박수경, “개도국의 기후변화 대응을 위한 국제사회의 지원: 논의동향 및 쟁점분석”, (대외 경제정책연구원(KIEP), 2010), 연구자료 10-07.

최동진, “수자원 관리의 패러다임 연구”, (한국법제연구원, 경제· 인문사회연구회 합동연구 총서, 010), 09-25-11, pp.

Francou, Bernard et al., "Tropical Climate Change Recorded by a Glacier of the Central Andes During the Last Decades of the 20th Century: Chacaltaya, Bolivia”, (AMBIO: A Journal of the Human Environment (AMBIO: Journal of the Human Environment), 2000) 29.

Mattos, Roger, "Información Sobre la Gestión del Agua en Bolivia", Comision para la Gestión Integral del Agua en Bolivia, 2000, http://www.aguabolivia.org/index.php?option=com_wrapper\&Itemid=94.

"El Cambio Climático en Bolivia (Análisis, Síntesis de Impactos y Adaptación)" (PDF), (Ministerio de Planificacion del Desarrollo, 2007)http://www.pncc.gov.bo/esp/pdf/publicaciones/20-IVARvulnerabilidad2.pdf

Sanchez-Triana, Ernesto et al., "Bolivia - Public policy options for the well-being of all. Chapter 19: Environmental Degradation” (PDF), (World Bank, 2006, pp. 421-437)

Smits, Step et al. (n.d.), "Integrated water resources management at the local level:the role of local government" (PDF), (European Commission Research Directorate General), http://www.icleieurope.org/fileadmin/user_upload/logowater/resources/Local_govt_and_IWRM_Smits-Busta mante-Butterworth.pdf

Viceministerio de Riego Julio, "Plan Nacional de Riego" (PDF), (Ministerio del Agua, 2007), http://www.riegobolivia.org/documentos/PlanNacionaldeRiego/PlanNacionaldeRiego.pdf

"Bolivia Agricultural Sector Review" (PDF), (World Bank, 1992)

http://imagebank.worldbank.org/servlet/WDSContentServer/IW3P/IB/1992/04/06/000009265_3961 001220038/Rendered/PDF/multi_page.pdf 
물 지속가능개발과 수자원 권리: “El agua y el derecho de acceso" (PDF), Agua Sustentable, http://www.aguasustentable.org/documentos/derechos/folleto.pdf

볼리비아 PRONAR 계획: "Plan Nacional de Riego-PRONAR” (PDF), http://www.riegobolivia.org/ documentos/PlanNacionaldeRiego/PlanNacionaldeRiego.pdf

볼리비아 긴급 구조 및 자연재해 관리 프로젝트: "Bolivia Emergency Recovery and Disaster Management Project" (PDF),

http://www-wds.worldbank.org/external/default/WDSContentServer/WDSP/IB/2008/03/11/000333

037_20080311001306/Rendered/PDF/410690PJPR0REP1y100IDA1R20081029612.pdf.

볼리비아 관개시설 프로젝트 디자인과 평가: "BO-T1039: Evaluation and Design of Irrigation Project", http://www.iadb.org/projects/Project

\section{2. 국제협력기구 관련 사이트 및 데이터}

\section{독일 국제개발기구: “GIZ”, http://www.giz.de/en/}

Joint Monitoring Program WHO/UNICEF(JMP/2006): http://www.wssinfo.org/data-estimates/introduction/ 세계은행 볼리비아 국가정보:

http://web.worldbank.org/WBSITE/EXTERNAL/COUNTRIES/LACEXT/BOLIVIA

World Bank (2003), "Water Resource Strategy",

http://water.worldbank.org/water/strategy-and-policies

World Bank (2003), "Private Sector Development Strategy",

http://water.worldbank.org/water/strategy-and-policies

World Bank (2003), "external Projects in Bolivia",

http:/ /web.worldbank.org/external/projects/main?query=Bolivia\&menuPK=51526214\&theSit ePK=40941\&page $\mathrm{PK}=218616 \&$ piPK $=217470$

볼리비아 수자원 부 (Ministerio del Agua 2008): http://www.mmaya.gob.bo/

볼리비아 기후변화 국가 프로그램 (National Program for Climate Change 2008), cited in http://unfccc.int/resource/docs/natc/boladd6.pdf

볼리비아 공공투자 및 대외 금융 차관부(Vice Ministry of Public Investment and External Financing 2010) 
볼리비아 농촌 및 농업외무부(Ministerio de Asuntos Campesinos y Agropecuarios) (2005): http:/ /www.mirabolivia.com/webpage.php?id_webpage=147

CIA World Factbook (2010): https://www.cia.gov/library/publications

EIA 통계자료 (2010): http://www.eia.gov/

IFS (2010): http://www.imfstatistics.org/IMF/expired.asp

EIU(2010): http://www.eiu.com/public/

화학물질정보 사이트 인용: http://www.nier.go.kr 